\title{
Modulation of PPAR- $\gamma$ by Nutraceutics as Complementary Treatment for Obesity-Related Disorders and Inflammatory Diseases
}

\author{
D. Ortuño Sahagún, ${ }^{1}$ A. L. Márquez-Aguirre, ${ }^{2}$ S. Quintero-Fabián, ${ }^{1,3}$ \\ R. I. López-Roa, ${ }^{3}$ and A. E. Rojas-Mayorquín ${ }^{4,5}$ \\ ${ }^{1}$ Laboratorio de Desarrollo y Regeneración Neural, Instituto de Neurobiología, Departamento de Biología Celular y Molecular, CUCBA, \\ Universidad de Guadalajara, camino Ing. R. Padilla Sánchez 2100, Las Agujas, 44600 Zapopan JAL, Mexico \\ ${ }^{2}$ Unidad de Biotecnología Médica y Farmacéutica, Centro de Investigación y Asistencia en Tecnología y Diseño del Estado de Jalisco A.C., \\ 44270 Guadalajara, JAL, Mexico \\ ${ }^{3}$ Departamento de Farmacobiología, CUCEI, Universidad de Guadalajara, Boulevard Marcelino García Barragán, \\ 44430 Tlaquepaque, JAL, Mexico \\ ${ }^{4}$ Departamento de Ciencias Ambientales, Instituto de Neurociencias, CUCBA, Universidad de Guadalajara, 45100, JAL, Mexico \\ ${ }^{5}$ Departamento de Investigación Básica, Instituto Nacional de Geriatría (INGER), Periférico Sur No. 2767, Col, San Jerónimo Lídice, \\ Delegación Magdalena Contreras 10200, México DF, Mexico
}

Correspondence should be addressed to D. Ortuño Sahagún, daniel_ortuno5@msn.com and A. E. Rojas-Mayorquín, argelia.rojas@gmail.com

Received 22 August 2012; Revised 3 October 2012; Accepted 23 October 2012

Academic Editor: Bruce Blumberg

Copyright ( 2012 D. Ortuño Sahagún et al. This is an open access article distributed under the Creative Commons Attribution License, which permits unrestricted use, distribution, and reproduction in any medium, provided the original work is properly cited.

\begin{abstract}
A direct correlation between adequate nutrition and health is a universally accepted truth. The Western lifestyle, with a high intake of simple sugars, saturated fat, and physical inactivity, promotes pathologic conditions. The main adverse consequences range from cardiovascular disease, type 2 diabetes, and metabolic syndrome to several cancers. Dietary components influence tissue homeostasis in multiple ways and many different functional foods have been associated with various health benefits when consumed. Natural products are an important and promising source for drug discovery. Many anti-inflammatory natural products activate peroxisome proliferator-activated receptors (PPAR); therefore, compounds that activate or modulate PPARgamma (PPAR- $\gamma$ ) may help to fight all of these pathological conditions. Consequently, the discovery and optimization of novel PPAR- $\gamma$ agonists and modulators that would display reduced side effects is of great interest. In this paper, we present some of the main naturally derived products studied that exert an influence on metabolism through the activation or modulation of PPAR- $\gamma$, and we also present PPAR- $\gamma$-related diseases that can be complementarily treated with nutraceutics from functional foods.
\end{abstract}

\section{Introduction}

Peroxisome proliferator-activated receptors (PPAR) are ligand-activated transcription factors belonging to the nuclear receptor superfamily of regulatory factors. They exercise homeostatic functions in the intestine at the interface between nutrient metabolism and immunity, and their main function is related with the regulation of genes involved in glucose and lipid metabolism [1-4].

In mammals, three isoforms have been identified $(\alpha$, $\beta / \delta$, and $\gamma$ ), which are encoded by separate genes. All PPAR isotypes form a heterodimeric complex with the retinoid $\mathrm{X}$ receptor (RXR), and the complex binds to the PPAR response element, which functions as the central regulator of cellular differentiation [5], apoptosis [6], inflammatory responses $[7,8]$, lipid metabolism, and metabolic disease [9]. Also, the farnesoid X receptor (FXR) is involved in adipogenesis, adipocyte differentiation, and lipid storage, increasing adiponectin through a mechanism partially mediated by PPAR-gamma (PPAR- $\gamma$ ) $[10,11]$.

PPAR $-\gamma$ is expressed generally in multiple tissues, such as lung, breast, ovary, placenta, and colon. It promotes cell 
differentiation, particularly as a potent master gene, as an inducer and regulator of adipocyte growth and differentiation, promoting their transition from small, quiescent adipocytes to large, activated adipocytes $[12,13]$ by a transcriptional cascade that controls the expression of a number of genes that are essential in lipid accumulation in adipocytes during the differentiation and also in mature adipocytes [13-15]. Moreover, it is a key gene involved in the control of hepatic peroxisomal $\beta$-oxidation of fatty acids [16]. Additionally, PPAR- $\gamma$ has been considered as a molecular target for cancer chemoprevention $[17,18]$. In addition, it possesses anti-inflammatory effects and increases insulin sensitivity [19]. More recently, PPAR- $\gamma$ has been shown to be involved also in the regulation of genes contributing to hypertension and atherosclerosis [20].

Adipose tissue is an important source of hormones and cytokines [21]. Therefore, selective PPAR- $\gamma$ agonists exert anti-inflammatory effects while regulating major metabolic pathways in abdominal fat [22]. However, the use of PPAR- $\gamma$ ligands is associated with an increased risk of cardiovascular ischemic events, as in the case of rosiglitazone [23]. In addition, other compounds that exert different effects on PPAR- $\gamma$, such as tri-methylbenzidine trinitrobenzene sulfonic acid (TNBS), which induced acute inflammation in the mesenteric tract, appear to support a role for this nuclear receptor in promoting the acquisition of a proinflammatory phenotype by mesenteric adipocytes [24].

Despite the fact that PPAR- $y$ activators are currently used as insulin sensitizers to combat type 2 diabetes and metabolic syndrome [25], PPAR- $\gamma$ agonists in clinical use, represented by thiazolidinediones (TZD), have serious side effects such as weight gain, increased bone fracture, fluid retention, and heart failure [26]. Conversely, natural products constitute an important and promising source for drug discovery [27]. Many anti-inflammatory natural products, especially dietary lipids such as linoleic acids, activate PPAR [28].

One of the main problems of using nutraceuticals for experimental research is that they are derived from natural sources, such as plant extracts and microbial products; therefore, in some cases, the active compounds that exert the biological action are not yet completely identified. Moreover, in many cases, the biological action is reduced, or even modified, when the compounds are fractionated or isolated; this is one of the major limitations of nutraceutical experimentation. Clearly, the whole comprises more than simple addition of the components, and this idea also applies to the use of nutraceuticals as dietary complements. In addition, the specific susceptibility, such as the particular physiologic and genomic characteristics of each individual, renders the action of nutraceuticals more complex because this generally implies a balance among many different elements, such as metabolic state, physiological performance, gene expression profiles, and, of course, the composition of the nutritional complements. Additionally, in many cases, the experimental information available remains scarce and in many respects also preliminary, most probably due to the difficulty represented in obtaining active extracts whose composition is not completely established.
In this context, we review diverse nutraceutics that are reported to be able to modulate PPAR- $\gamma$ expression or action and that could in turn be employed as complementary treatment for obesity-related disorders and some inflammatory diseases, reducing the side effects exhibited by commonly used pharmacological drugs.

1.1. Diet and Lifestyle. A direct correlation between adequate nutrition and health is a universally accepted truth; "we are what we eat." Geopolitical diversity, modern science, and economic changes have resulted in the development of new social food habits. Continued changes in the processing technologies to meet consumer preferences and lifestyle changes have caused the present state of increased caloric intake, sedentary habits, overconsumption of high energy foods due to increased portion sizes, and low intake of functional foods, resulting in a significant increase in the prevalence of several chronic degenerative diseases, such as type 2 diabetes, cardiovascular diseases, neurodegenerative diseases, and inflammatory diseases [29].

Worldwide, over 1 billion adults and $10 \%$ of children can be classified as overweight or obese [30]. Their average life expectancy is already diminished, and main adverse consequences range from cardiovascular disease, type 2 diabetes, metabolic syndrome, and several cancers, which are currently engaged in a devastating epidemic spread throughout the world. Compounds that activate or modulate PPAR- $\gamma$ may aid in fighting all of these pathological conditions [25].

1.2. Functional Foods. The European Commission's Concerted Action on Functional Food Science in Europe (FuFoSE), coordinated by International Life Science Institute (ILSI) Europe, described functional foods as follows:

\section{"A food can be regarded as 'functional' if it is satisfactorily demonstrated to affect beneficially one or more target functions in the body, beyond adequate nutritional effects, in a way that is relevant to either an improved state of health and well-being and/or reduction of risk of disease. Functional foods must remain foods and they must demonstrate their effects in amounts that can normally be expected to be consumed in the diet: they are not pills or capsules, but part of a normal food pattern." [31, 32].}

Functional foods contain bioactive substances, nutraceutics, which can be classified as micronutrients (vitamins and fatty acids) and nonnutrients (phytochemicals and probiotics) (Table 1). These components, with a wide range of chemical structures and functionality, provide different beneficial effects beyond simple nutrition, resulting in improved health. Fruits and vegetables are rich sources of a wide range of vital micronutrients as follows: vitamins (provitamin A, carotenoids, vitamin C, and folate), phytochemicals (nonprovitamin A carotenoids and polyphenols), and fiber (a high proportion of nondigestible carbohydrate polymers such as cellulose, pectin, and fructans). The influence of nondigestible carbohydrate polymers (prebiotics) on 
TABLE 1: Functional foods classification, some sources, and examples of bioactive substances.

\begin{tabular}{|c|c|c|c|}
\hline Functional food & \multicolumn{2}{|c|}{ Bioactive component (nutraceutic) } & Source $(\mathrm{s})$ \\
\hline \multirow[t]{2}{*}{ Micronutrients } & Vitamins & $\begin{array}{c}\text { Retinol (vitamin A) } \\
\alpha \text {-tocopherol (vitamin E) } \\
\text { Calciferol (vitamin D3) }\end{array}$ & Walnuts, almonds, hazelnuts, spinach, fish oil \\
\hline & $\begin{array}{l}\text { Polyunsaturated fatty } \\
\text { acids (PUFAs) }\end{array}$ & $\begin{array}{c}\text { Omega } 3 \text { Fatty acids: } \\
\text { eicosapentaenoic acid (EPA) } \\
\text { docosahexaenoic acid (DHA) }\end{array}$ & Salmon, tuna and others fish oils \\
\hline \multirow{5}{*}{$\begin{array}{l}\text { Nonnutrients } \\
\text { Phytochemicals }\end{array}$} & Carotenoids & $\begin{array}{l}\text { Beta-carotene } \\
\text { luteín, zeaxanthin } \\
\text { lycopene }\end{array}$ & $\begin{array}{l}\text { Carrots, pumpkin, collards, kale, spinach, } \\
\text { tomatoes, watermelon }\end{array}$ \\
\hline & Phenolic acid derivatives & $\begin{array}{l}\text { Caffeic acid } \\
\text { Ferulic acid } \\
\text { Gallic acid } \\
\text { Curcumin }\end{array}$ & Coffee, pears, apples, corn, curcumin, vanilla \\
\hline & Flavonoids & $\begin{array}{l}\text { Flavonols (quercetin) } \\
\text { Isoflavones } \\
\text { Coumarins } \\
\text { Anthocyanidines } \\
\text { Stilbenes (resveratrol) }\end{array}$ & $\begin{array}{l}\text { Berries, cherries, red grapes, tea, cocoa, } \\
\text { apples, citrus fruits, onion, broccoli, } \\
\text { cranberries, strawberries, soybeans }\end{array}$ \\
\hline & Sulfides/thiols & $\begin{array}{l}\text { Diallyl sulfide } \\
\text { S-allyl cysteine sulfoxide } \\
\text { 1,2-viniyldithiin }\end{array}$ & Garlic, onions, banana, cruciferous vegetables \\
\hline & Dietary fiber (prebiotic) & $\begin{array}{c}\text { Fructooligosaccharides } \\
\text { Neoglicans }\end{array}$ & $\begin{array}{l}\text { Whole grains, onions, chicory, agave, some } \\
\text { fruits }\end{array}$ \\
\hline Probiotics & PUFAs induction & $\begin{array}{l}\text { Saccharomyces cerevisiae (var. boulardii) } \\
\text { Bifidobacteria and } \\
\text { Lactobacillus genus } \\
\text { Escherichia coli strain Nissle1917 (EcN) } \\
\text { Compound VSL3 }\end{array}$ & $\begin{array}{l}\text { Certain yogurts and other cultured dairy and } \\
\text { no-dairy applications }\end{array}$ \\
\hline
\end{tabular}

intestinal health, through viscosity, modification of foods during their transition through the gastrointestinal tract, immunity modulation, prevention of inflammation, and the maintenance of an ideal population of microbiotics (probiotics) is continuously being unraveled, whereas secondary plant products such as carotenoids, polyphenols, sulforaphanes, indoles, and essential oils, in conjunction with a milieu of polymeric substances from fruits and vegetables, enhance the healthfulness of foods [33].

Some of these nutraceutics have been reported to be able to modulate PPAR- $\gamma$ expression or action and could in turn be used as complementary treatment for obesityrelated disorders and inflammatory diseases. In Table 2, we summarize some of the effects exerted on PPAR- $\gamma$ by nutraceutics.

\section{Micronutrients}

According to the World Health Organization (WHO), certain nutrients are called micronutrients because they are needed only in minuscule amounts; these substances are the "magic wands" that enable the body to produce enzymes, hormones, and other substances essential for proper growth and development.

2.1. Beta-Carotene, Vitamin A, and Its Derivatives. In mammals, beta-carotene (BC) is the natural precursor for apocarotenoid molecules including retinoids (vitamin $\mathrm{A}$ and its derivatives) [34]. There is increasing evidence of an impact of $\mathrm{BC}$, vitamin $\mathrm{A}$, and its derivatives as signaling molecules that can influence adipocyte physiology by acting on parameters related with adiposity in humans [35]. Circulating BC levels are inversely correlated with the risk of human type 2 diabetes [36-39]. Additionally, reduced plasma levels of carotenoids, including BC, are commonly found in obese children [40].

An important metabolic linkage is carried out by the BC 15,15' -monooxygenase (Bcmol), which converts BC into all-trans-retinal and is the primary enzyme for retinoid production [41]. Bcmo1 knockout mice are highly susceptible to high fat diet-induced obesity and show increased expression of PPAR- $\gamma$-regulated genes in fat depots [41]. Bcmol gene expression is under the control of PPAR- $\gamma[42$, 43 ] and is induced during adipocyte differentiation [44]. The primary BC cleavage product, retinaldehyde, has been shown 
TABLE 2: Modulation of PPAR- $\gamma$ by nutraceutics.

\begin{tabular}{|c|c|c|}
\hline Bioactive (nutraceutic) & Effect on PPAR- $\gamma$ & Ref. \\
\hline Retinaldehyde & Inhibit PPAR- $\gamma$ activity in adipocyte cell cultures and mouse models & {$[45]$} \\
\hline$\beta$-apo-149-carotenal & Inhibit PPAR- $\gamma$ activity and adipogenesis in adipocyte cell culture & {$[46]$} \\
\hline$\alpha$ - and $\gamma$-tocopherol & Activate PPAR- $\gamma$ expression in colon cancer cells & {$[47,48]$} \\
\hline $\begin{array}{l}\text { Retinoic acid and 1,25-dihydroxy } \\
\text { vitamin D3 }\end{array}$ & $\begin{array}{l}\text { Inhibited adipocyte differentiation of } 3 \mathrm{~T} 3-\mathrm{L} 1 \text { preadipocytes by repressing the } \\
\text { upregulated protein expression of PPAR- } \gamma 2\end{array}$ & {$[49]$} \\
\hline N3 fatty acids from fish oil & Increases adiponectin level and upregulates PPAR- $\gamma$ & {$[50,51]$} \\
\hline Linoleic acid & $\begin{array}{l}\text { Agonist for PPAR- } \gamma \\
\text { Activation of PPAR- } \alpha \text { and }-\gamma\end{array}$ & $\begin{array}{l}{[52]} \\
{[53]}\end{array}$ \\
\hline Quercetin & Inhibited activation of all three isoforms of PPAR & {$[54]$} \\
\hline Banana lectin and garlic lectin & $\begin{array}{l}\text { Exert an adipogenic effect on mesenchymal cells and upregulate PPAR- } \gamma 2 \\
\text { expression }\end{array}$ & {$[55]$} \\
\hline 1,2-vinyldithiin (1,2-DT) (from garlic) & $\begin{array}{l}\text { Inhibits differentiation and inflammation of human preadipocyte in vitro by a } \\
\text { reduction in expression of PPAR- } \gamma 2\end{array}$ & {$[56]$} \\
\hline Curcumin & Activates PPAR- $\gamma$ in colon cancer cell line & {$[57]$} \\
\hline Resveratrol & Downregulates PPAR- $\gamma$ 1-3 mRNA expression in human visceral adipocytes & {$[58]$} \\
\hline Lanostane triterpenes & Suppress PPAR- $\gamma$ expression in 3T3-L1 cells & {$[59]$} \\
\hline $\begin{array}{l}\text { Fructooligosaccharides and } \\
\text { mannooligosaccharides }\end{array}$ & Induced PPAR- $\gamma$ in Caco- 2 cells & {$[60]$} \\
\hline Neolignans & PPAR- $\gamma$ agonists & {$[61]$} \\
\hline \multirow[t]{2}{*}{ S. boulardii } & $\begin{array}{l}\text { Upregulated PPAR- } \gamma \text { expression in human colonocytes and in HT- } 29 \text { colonic } \\
\text { epithelial cells }\end{array}$ & {$[62]$} \\
\hline & Inhibited TNF- $\alpha$-mediated regulation of PPAR- $\gamma$ & {$[63]$} \\
\hline
\end{tabular}

PPAR: Peroxisome proliferation-activated receptor; PPAR- $\gamma$ : PPAR-gamma; S. boulardii: Saccharomyces boulardii.

to inhibit PPAR- $\gamma$ activity both in adipocyte cell cultures and mouse models [45]. Furthermore, evidence has been provided that Bcmol plays an important role in Retinoic acid (RA) production and in RA receptor (RAR) signaling in adipocytes [44].

Additionally, BC-derived long-chain apocarotenoids, such as $\beta$-apo-149-carotenal, can inhibit PPAR- $\gamma$ activity and adipogenesis in cell culture [46]. Moreover, $\beta-13$ apocarotenone has been shown to inhibit retinoid $\mathrm{X}$ receptor alpha $(\mathrm{RXR} \alpha)$ activity [64]. Thus, reduction of PPAR- $\gamma$ activity and downregulation of its target genes likely explain the reduced adiposity of WT mice upon BC supplementation.

Therefore, BC plays an important role in the control of body adiposity in mice and Bcmol is a critical molecular player for the regulation of PPAR- $\gamma$ activity in adipocytes and also comprised a key component for crosstalk between RAR- and PPAR- $\gamma$-signaling pathways in control of body adiposity [65]. However, the complete specific mechanisms remain to be elucidated. Ongoing studies will offer new insights into adipose physiology and the mechanisms for the regulation of glucose and lipid metabolism by retinoids. These studies will contribute to further understanding of the factors important for adipose tissue development and may lead to future therapeutic interventions. These may include the development of small molecules that directly target adipose tissue development.

2.2. Vitamin E: Alpha-Tocopherols and Tocotrienols. Vitamin $\mathrm{E}$ is a fat-soluble vitamin that is essential for humans [66]. The vitamin E family comprises eight lipophilic, naturally occurring compounds that include four tocopherols (with a saturated phytyl tail) and four tocotrienols (with an unsaturated isoprenoid side chain) designated as $\alpha, \beta$, $\gamma$, and $\delta$ [67]. The $\alpha$ - and $\gamma$-tocopherols are the most common dietary tocopherols due to their high amounts in commercially produced vegetable oils such as soybean, corn, and cottonseed [68, 69]. Alpha tocopherol has been considered the classic "vitamin E" because it is the major tocopherol found in plasma and tissues [69].

Both $\alpha$ - and $\gamma$-tocopherol have been shown to activate PPAR- $\gamma$ expression and transactivation in colon cancer cells, and $\gamma$-tocopherol is a better modulator of PPAR- $\gamma$ expression than is $\alpha$-tocopherol $[47,48]$. Analogs of PPAR- $\gamma$ ligands, $\alpha$-, $\gamma$-, and mixed tocopherols, are important for the inhibition of cancer in animals $[17,18,70,71]$, suggesting that $\gamma$ and $\delta$-tocopherols should be considered as anticancerogenic nutraceutics for studies in humans. 
Tocotrienols are naturally occurring compounds that appear to be nontoxic; therefore, they are used as dietary supplements in some studies, with the ultimate goal of preventing some of the damage attributable to dysregulated inflammatory responses associated with aging. A recent evaluation of the anti-inflammatory properties of dietary supplementation with quercetin and $\delta$-tocotrienol, two naturally occurring proteasome inhibitors, in vivo in mice [72] and in chickens [73], demonstrate a reduction in serum tumor necrosis factor-alpha (TNF- $\alpha$ ) and nitric oxide (NO) levels.

Additionally, findings from various studies suggested that tocotrienols exert a direct effect on lipidic metabolism, with a hypocholesterolemic or antiatherogenic effect on humans, rats, and mice. In vitro studies demonstrated that tocotrienols act as the 3-hydroxy-3-methyl-glutarylCoA reductase (HMGCR) inhibitor and consequently reduce cholesterol synthesis. For example, oral administration of a tocotrienol-rich fraction (TRF) of palm oil, which contains $\gamma$-tocotrienol, decreases body fat levels in rats. Additionally, in an in vitro study, TRF suppressed adipocyte differentiation and Akt phosphorylation in 3T3-L1 preadipocytes, through the suppression of the insulin-induced PPAR- $\gamma$ mRNA expression [74].

These data show the possibility that tocotrienol could be an antiadipogenic vitamin, similar to vitamin A, with regard to nutrient-mediated regulation of body fat through its effects on differentiation. However, further study is required to determine whether tocotrienol could effectively promote the loss of body fat in humans.

2.3. Retinoic Acid and 1,25-Dihydroxy Vitamin D3 (1,25 $(\mathrm{OH}) 2 \mathrm{D} 3)$. Retinoic acid (RA) influences adipocyte differentiation [75, 76] and fat deposition [77] and the expression of adipokines such as leptin, resistin, and the serum retinolbinding protein [78-81]. Part of these effects is mediated via RAR [82], which can interfere with the activity of PPAR$\gamma[76,77]$. In addition, RA may influence PPAR-mediated responses by activating the RXR moiety of permissive PPAR:RXR heterodimers [83] and, possibly, by serving as an agonist of PPAR- $\beta / \delta[49,84]$.

RA and the 1,25-dihydroxy vitamin D3 (1,25 (OH)2 D3) inhibited adipocyte differentiation of 3T3-L1 preadipocytes by repressing the upregulated protein expression of PPAR- $\gamma 2$ [85]. The active form of vitamin $\mathrm{D},(1,25(\mathrm{OH}) 2 \mathrm{D} 3)$, inhibits adipogenesis in the bone marrow of SAM-P/6 mice and is associated with reduction in PPAR- $\gamma 2$ expression [86].

\subsection{N3 Polyunsaturated Fatty Acids (PUFAs)}

2.4.1. PUFAs-Omega-3 Fatty Acids: DHA/EPA from Fish Oil. The beneficial effect of fish oil (FO) has been demonstrated in several human diseases, including cardiovascular diseases [87], autoimmune inflammatory diseases, rheumatoid arthritis, inflammatory bowel disease, osteoporosis [88], sepsis, vascular compliance, blood pressure [89], and diabetes [90], among other pathologies. FO has been shown to have beneficial effects on glucose and lipid metabolism in studies with rodents, to improve insulin sensitivity [91, 92], to reduce triglycerides [93], and to improve bone mineral density (BMD) in ovariectomized mice [88].

Along with lowering of plasma triglycerides, FO also reduces blood pressure, inflammation, thrombosis, and arrhythmia, contributing to its role in lowering risk of cardiovascular disease and diabetes (reviewed in $[50,94]$ ). In addition, FO supplementation increases adiponectin levels and up-regulates PPAR- $\gamma[51,95]$.

The n-3 polyunsaturated fatty acids (PUFAs) of FO, eicosapentaenoic acid (EPA) and docosahexaenoic acid (DHA), are endogenous ligands for PPAR; therefore, they mediate the insulin-sensitizing, lipid-lowering, and antiinflammatory properties of FO [96]. Not only the n-3 fatty acids, but also their metabolites are potent PPAR- $\gamma$ agonists [97]. The interaction between FO and PPAR plays a critical role in regulating glucose and lipid metabolism in liver (reviewed in $[98,99]$ ) and in adipose tissue (reviewed in [96]). Thus, FO mediates its beneficial effects on metabolic syndrome by improving adipose tissue storage and secretory functions and by reducing inflammation.

Finally, it has been hypothesized that derivatives from EPA and DHA (from FO) are stronger PPAR agonists than their parent compounds. Small changes in the molecular structure of these fatty acids exert a great influence on activating different PPAR. Structural information, as well as ligand-binding assays and gene transactivation, has been employed in the designing of new dual-action drugs against diabetes and metabolic syndrome. These derivative molecules may also be utilized as anti-inflammatory and anticancer agents [100].

2.4.2. PUFAs-Conjugated Linoleic Acid. Conjugated linoleic acid (CLA) is a class of geometric and positional conjugated dienoic isomers produced during biological or industrial hydrogenation of linoleic acid (C18:2, n-6, c9, and c12). The major dietary sources of CLA are ruminant meat, dairy products, and partially hydrogenated vegetable oils [101]. In fact, PUFAs and their metabolites, including CLA, are endogenous PPAR- $\gamma$ ligands $[52,102]$. CLA was found to be a potent naturally occurring agonist for PPAR- $\gamma$ [103].

N-3 PUFAs (i.e., linoleic acid, DHA, and EPA) elicit potent anti-inflammatory and immunoregulatory properties either directly $[104,105]$ or following transcellular processing that results in the generation of hydroxy-containing n-3 PUFAs metabolites [106].

Recently, there has been extensive interest in the potential health benefits of dietary supplementation with CLA, including anti-carcinogenic and antitumorigenic effects [53], reduction in the risk of atherosclerosis, hypertension, and diabetes, improvement in food efficiency, promotion of energy metabolism, and an antiosteoporotic and positive effect on immune function [107]. Also, dietarysupplemented CLA is able to suppress cardiomyocyte hypertrophy through activation of PPAR- $\alpha$ and $-\gamma$ [108]. Additionally, because, CLA profoundly reduces body fat stores in several species, including pig, rat, hamster, chicken, and mouse [109], it is popularly employed as a weightloss management strategy $[107,110]$. In addition, CLA has 
numerous additional reported benefits, including altering body composition, improving lipid profiles, modifying both innate and adaptive immune responses, and improving insulin resistance (reviewed in [111]).

However, CLA has been shown to exhibit some adverse effects [112], including reduction in insulin sensitivity in subjects with type 2 diabetes [113] and augmentation of the pre-existing insulin resistance $[114,115]$. Additionally, longterm studies in rodents have demonstrated a lipodystrophic effect of CLA [116] that is associated with decreased plasma adiponectin and leptin levels and increased insulin resistance [117].

To overcome these adverse effects, a combination of CLA plus FO has been suggested for dietary supplementation during clinical trials in obese, insulin-resistant aging patients in order to prevent osteoporosis [118]. This could result in an excellent strategy in the management of fat-mass reduction and osteoporotic bone loss, circumventing CLA-induced hepatomegaly and insulin resistance, although additional studies in humans are still required before the use of $\mathrm{CLA}+\mathrm{FO}$ as a dietary supplement to reduce obesity and osteoporosis in humans [118].

Two main mechanistic theories have been proposed to explain the immune-enhancing effects of dietary CLA: a PPAR- $\gamma$-dependent and a PPAR- $\gamma$-independent pathway [102]. In vitro studies have also indicated that the PPAR- $\gamma$ activating capabilities of CLA are cell type-dependent and isomer-specific [102], and in vivo, PPAR- $\gamma$ gene expression has been proposed as a mediator of CLA effects [119]. In support to this theory, it has been reported that dietary n-3 PUFAS (DHA and EPA) in a mutant mice could reduce hypertrophy and hyperplasia of fat cells in vivo. This inducible and reversible model of lipoatrophy was achieved by selective ablation of PPAR- $\gamma$ in response to tamoxifen [120].

\section{Phytochemicals}

Phytochemicals are non-nutritive plant chemicals that possess protective or disease-preventive properties. They are nonessential nutrients, meaning that the human body does not require them for sustaining life.

3.1. Isoflavones and Flavonoids. Botanical compounds such as isoflavones may be agonists or activators of the "promiscuous" PPAR nuclear receptors regulating lipid metabolism in the cell [54, 121-123], and glucose tolerance [54]. Isoflavone intake is altering lipid metabolism in a manner consistent with activation of PPAR- $\gamma$ and also via a PPAR$\gamma$-independent mechanism [124], possibly mediated by PPAR- $\gamma$ activation. In particular, genistein, a soy isoflavone, has been identified as a ligand of the PPAR- $\gamma$ receptor [121].

In contrast, flavonoids such as quercetin inhibited the activation of all three isoforms of PPAR [55], but its metabolites upregulated PPAR- $\gamma$ expression [125] and could alleviate hepatic fat accumulation [126]. In addition, chickens fed diets supplemented with quercetin appear to prevent some of the damage attributable to the dysregulated inflammatory responses associated with aging by reducing serum levels of TNF- $\alpha$ and NO [73]. Additionally, some phytoestrogens, including soy isoflavones, have revealed their potential for inducing hormone-dependent cancers (breast and endometrium), leading to safety concerns [127]. Thus, a maximum daily intake level for phytoestrogens has been suggested in several countries [128].

3.2. Lectins. Lectins form an unavoidable component of the vegetarian diet; yet, their effects on various tissues have not been extensively studied. Many of the reported studies have focused their attention on gastrointestinal tract or on immune system with respect to allergic responses. However, it is relevant to examine the effects of apparently nontoxic dietary lectins on animal tissues and humans regarding its adipogenic effect [129]. Two dietary lectins isolated from common foods usually consumed in an unprocessed form are Banana lectin (BL) and Garlic lectin (GL). Oral administration of these lectins resulted in an enhanced hematopoietic stem progenitor cell pool of mice [130]. In addition, both lectins, BL and GL, exert an adipogenic effect on these mesenchymal cells and significantly upregulate PPAR- $\gamma 2$ expression [129], an effect comparable to that mediated by insulin. Both of these lectins interact with the insulin receptor in this cell line and activate the Mitogen-activated protein kinase kinase (MEK)-dependent Extracellular signal-regulated kinase (ERK) pathway [130]. Therefore, it is possible to use specific subfragments or peptide sequences derived from these lectins to develop agonists or antagonists of insulin receptor-mediated signaling to further examine the in vivo effects of dietary lectins on tissue homeostasis [129].

3.3. Alliin and Allicin from Garlic (Allium Sativum). Garlic has been used for 5,000 years, not only as a culinary spice, but also as a medicinal herb due to its antibacterial and antiinfectious properties. It has been utilized to treat a variety of health problems $[131,132]$ due to its high content of organosulfur compounds and its antioxidant activity.

The main active component in garlic is the S-allyl cysteine sulfoxide, commonly called alliin, which presents a cardioprotective effect in a model of myocardial infarct [56]. In addition, alliin reduce the levels of TNF- $\alpha$ in humanumbilical-vein endothelial cells and helps to decrease serum levels of glucose, insulin, triglycerides, and uric acid, as well as insulin resistance, when compared with fructose-fed rats $[133,134]$.

Another organosulfurated compound from garlic is 1,2-vinyldithiin (1,2-DT) [135], a lipophilic component found mainly in oily macerates of crushed garlic, arising from the degradation of allicin [136]. This 1,2-DT inhibits the differentiation and inflammation of the human preadipocyte in vitro, an effect that is mediated by a significant reduction in the expression of the following key major adipogenic-transcription factors: PPAR- $\gamma 2$ and CCAAT-enhancer-binding protein CCAAT-enhancerbinding protein-alpha (C/EBP)- $\alpha$, induced by $1,2-\mathrm{DT}$ during human preadipocyte differentiation [137]. This suggests that 
the negative effect of 1,2-DT on preadipocyte differentiation could be mainly due to an inhibitory effect on PPAR- $\gamma 2$ and on its target gene, lipoprotein lipase $(L P L)$, regardless of the period of exposure in human primary preadipocytes [137]. As a consequence, 1,2-DT could constitute an original dietary supplement in the treatment of obesity and its associated pathologies by limiting the expansion and inflammation of human white adipose tissue.

On the other hand, another constituent derived from garlic, diallyl disulfide, was shown to accelerate the differentiation of 3T3-L1 cells via PPAR- $\gamma$ activation [138]. In addition, our recent observations (unpublished) indicated that exposure of 3T3-L1 adipocytes to alliin is able to suppress LPS-evoked molecular inflammatory signals by causing a decrease in the messenger RNA (mRNA) expression level of pro-inflammatory genes (IL-6, MCP-1, and Egr-1) in this in vitro model of adipose tissue [139]. Therefore, more research continued to be needed to elucidate the complete molecular mechanism.

3.4. Curcumin, the Indian Spice Turmeric (Zingiberaceae). Curcumin is an antioxidant, anti-inflammatory, active principal ingredient of the curry spice, turmeric. The compound is marketed as a dietary supplement [140] and has attracted interest as a cancer-preventive agent [57].

It is well known that curcumin prevents the onset of inflammation by inhibiting the activation of nuclear factorkappa beta $(\mathrm{NF}-\kappa \mathrm{B})$, the production of TNF- $\alpha$, interferongamma (IFN- $\gamma)$, and $\mathrm{NO}$, and the gene expression of inducible nitric oxide synthase (iNOS) [141-143]. It acts by transrepressing $\mathrm{NF}-\kappa \mathrm{B}$, activating protein-1, and the signal transducer and activator of transcription-1 [144-148].

Curcumin activates PPAR- $\gamma$ in Moser cells, a human colon cancer cell line [145], and is able to suppress sepsis through PPAR- $\gamma$ [146]. In addition, it increased PPAR and decreased iNOS gene expression in infected macrophages, as well as downregulated IFN- $\gamma$ production by primed lymphocytes [147]. Curcumin action on PPAR could involve a curcumin-responsive element that resides in the PPAR- $\gamma$ gene regulatory region [148].

3.5. Resveratrol: A Phytoalexin from Grapes. Resveratrol is a naturally occurring polyphenolic compound with strong antioxidant properties and is found in abundance as a component of red wine and blackberries. Research has described several beneficial properties of this compound, including anti-carcinogenic, antiaging, neuroprotective, analgesic, antidiabetic, and antiobesity effects (reviewed in [149]).

Related with their antidiabetic and anti-obesity effects, PPAR- $\gamma$ is one of the targets of resveratrol [58], which partially mediates its antiadipogenic and proapoptotic effects in 3 T3-L1 adipocytes $[150,151]$ by preventing TNF- $\alpha$-induced suppression of adiponectin expression [152]. Also, resveratrol induces changes in white adipose-tissue metabolism in rats [59] and up-regulates SIRT1, FOXO1, and adiponectin, down-regulating PPAR- $\gamma 1-3$ mRNA expression in human visceral adipocytes [153]. In addition, resveratrol prevents the impairment of advanced glycosylation end-products
(AGE) on macrophage lipid homeostasis by suppressing the receptor for AGE via PPAR- $\gamma$ activation [154].

3.6. Triterpenes and Polysaccharides from the Medicinal Mushroom Ganoderma lucidum. A dietary supplement containing triterpenes and polysaccharides extracted from the medicinal mushroom G. lucidum is effective in inhibiting proliferation, invasive behavior, and angiogenesis in different cancer models and also as a treatment for atherosclerosis (reviewed in [155]). Very recently, a positive effect of G. lucidum on the metabolic syndrome has been investigated. Treatment of 3T3-L1 cells with G. lucidum extract significantly promoted adipocyte differentiation and adiponectin production in a dose-dependent manner [156]. This effect is suppressed by GW9662, a PPAR- $\gamma$ inhibitor, suggesting the involvement of this receptor [156]. Also, certain G. lucidum-derived lanostane triterpenes are able to suppress PPAR- $\gamma$ expression in 3T3-L1 cells [60], and a dietary supplement, ReishiMax, containing triterpenes and polysaccharides extracted from $G$. lucidum affects adipocyte differentiation and glucose uptake in 3T3-L1 cells [157] through decrease in the expression of PPAR- $\gamma$, sterol regulatory binding protein (SREBP)-1c, and $\mathrm{C} / \mathrm{EBP}-\alpha$, which regulate the genes responsible for the synthesis and transport of fatty acids. Therefore, ReishiMax could inhibit adipocyte differentiation/lipid accumulation through the following: (a) down-regulation of the expression of transcription factors PPAR- $\gamma$, SREBP-1c and C/EBP$\alpha$, and (b) suppression of the expression of the genes responsible for lipid synthesis (FAS, ACS1), lipid transport (FABP4, FATP1), and lipid storage (perilipin, PLIN) [158].

\section{Dietary Fiber}

Several studies report interest in nondigestible carbohydrates, which are prone to fermentation by gut microbiota in the control of obesity and related metabolic disorders [158]. Carbohydrates showing a prebiotic effect have received special attention in this context, because they have been shown-mainly in experimental animal studies - to regulate food intake and weight gain, as well as metabolic disorders associated with obesity, such as liver steatosis, dyslipidemia, diabetes, and/or even hypertension $[61,158,159]$.

4.1. Oligosaccharides. Fructooligosaccharides (FOS) and mannooligosaccharides are the most frequently encountered commercial forms of nondigestible carbohydrate polymers (prebiotics). These complex oligosaccharides contain 3-10 monosaccharide residues covalently linked through glycosidic bonds. Incubation of Caco-2 cells with both oligosaccharides induced PPAR $-\gamma$. PPAR $-\gamma$ regulates PGlyRP3 expression and triggers oligosaccharide-induced anti-inflammatory effects [160]. Antagonizing PPAR- $\gamma$ by culturing the cells with GW9662 for $24 \mathrm{~h}$ inhibited oligosaccharide-induced PGlyRP3 production and the antiinflammatory effect of the oligosaccharides. Therefore, oligosaccharides may exert an anti-inflammatory effect by inducing PPAR- $\gamma$, which regulates anti-inflammatory PGlyRP3 [160]. Consequently, prebiotic oligosaccharides 
may modulate the inflammatory state by a direct antiinflammatory effect. This effect appears to be PPAR- $\gamma$ dependent and at least in part depends on PGlyRP3 expression.

4.2. Neolignans from Magnolia officinalis. The term neolignan was defined by Gottlieb in 1978 [161] as including the lignans and also related compounds in which the two $\mathrm{C}_{6} \mathrm{C}_{3}$ units are joined by other bonds (e.g., 3-3' instead of $8-8^{\prime}$ ). In a review of natural resins, Haworth [162] proposed that the class of compounds derived from two $\mathrm{C}_{6} \mathrm{C}_{3} \beta, \beta^{\prime}$-linked units should be called lignans (his original spelling was lignane, but the " $\mathrm{e}$ " was deleted in subsequent publications).

Recently, in a computer-assisted search for PPAR- $\gamma$ agonists by three-dimensional (3D) structure homology, some neolignans emerge as strong candidates. Two of these, dieugenol and tetrahydrodieugenol, can be isolated from Magnolia officinalis Rehd. et Wils. bark with the use of different chromatographic methods [163]. These naturally derived compounds act as partial PPAR- $\gamma$ agonists; both exhibited higher affinity for PPAR- $\gamma$ than for the clinically used agonist pioglitazone (Actos) and were identified as selective activators of PPAR- $\gamma$, but not of PPAR- $\alpha$ or of $\operatorname{PPAR}-\beta / \delta$. In addition, these compounds induced adipocyte differentiation in 3T3-L1 cells in a PPAR- $\gamma$-dependent manner. The activation pattern exhibited from 1 and 2 renders them highly interesting, novel PPAR- $\gamma$ agonists that have the potential to be explored further which may lead to the development of novel pharmaceuticals or dietary supplements [163].

\section{Probiotics}

As defined in the previous section, prebiotics are nondigestible food components that beneficially affect the human body through modulation of the intestinal microbiota by selectively stimulating the growth and/or activity of some bacteria species in the colon, which are denominated "probiotics" $[161,164]$.

Probiotics are unicellular endosymbionts (microbes), such as lactic acid bacteria, bifidobacteria, yeast, and bacilli, which are thought to be beneficial to the host organism. The beneficial effects of probiotics extend outside of the intestine and have been shown to exert beneficial effects in obesity; nonalcoholic steatohepatitis (NASH) and diabetes, despite the molecular and cellular mechanisms mediating these effects, have not been completely elucidated [165].

5.1. Saccharomyces cerevisiae. The yeast Saccharomyces cerevisiae variety boulardii ( $\mathrm{Sb}$ ) has been prescribed over the past 30 years for prophylaxis and treatment of diarrheal diseases caused by bacteria and has been shown to provide intestinal protection against various enteric pathogens [166]. Indeed, Saccharomyces boulardii protected the host through multiple mechanisms such as inhibition of pathogen adhesion [167], neutralization of bacterial virulence factors [168], maintenance of epithelial barrier integrity [62], a decrease in pathogen-associated inflammation [161], and stimulation of the immune system [63]. This yeast has been shown to modulate pro-inflammatory signaling pathways leading to the inhibition of mitogen-activated protein kinases (MAPK) and NF- $\kappa$ B activation in intestinal epithelial cells (IEC) [63, $169,170]$.

The yeast Sc (strain CNCM I-3856) modulates transcript and protein expressions involved in inflammation, recruitment, and activation of immune cells in differentiated porcine intestinal epithelial IPEC-1 cells. Viable Sc inhibits enterotoxigenic Escherichia coli-(ETEC-) induced expression of pro-inflammatory transcripts (IL-6, IL-8, CCL20, CXCL2, and CXCL10) and proteins (IL-6 and IL-8). This inhibition was associated with a decrease of ERK1/2 and p38 MAPK phosphorylation, agglutination of ETEC by Sc, and an increase in the anti-inflammatory PPAR- $\gamma$ mRNA level [171] to mediate anti-inflammatory effects.

S. boulardii upregulated PPAR- $\gamma$ expression in human colonocytes and in HT-29 colonic epithelial cells [172] and raised the transcription of this receptor in the colon of animals exposed to TNBS ([172], and reviewed in [173]). Also, S. boulardii inhibited TNF- $\alpha$-mediated regulation of PPAR- $\gamma$ and IL- 8 by blocking activation of NF- $\kappa \mathrm{B}$ [174].

5.2. Escherichia coli. The Escherichia coli strain Nissle 1917 $(\mathrm{EcN})$ was isolated by A. Nissle in 1917 from the feces of a soldier who was nearly the only one who did not develop enterocolitis during the war on the Balkan peninsula [175]. At present, this bacterium is contained in a probiotic drug called Mutaflor, whose efficacy against inflammatory states in lower gastrointestinal tract has been demonstrated in numerous trials (reviewed in [176]). EcN draw out a number of favorable effects in the gut, including enhancement of their barrier function, a modulator effect on its motility, and a reduction in the formation and secretion of proinflammatory cytokines; it also exhibits an antagonistic activity against pathogenic bacteria in the gastrointestinal tract, induces immunomodulatory effects, and provide support of colonocyte metabolism (reviewed in [177]).

The gastroprotective activity of EcN could be at least partially attributed to modulation of PPAR expression. In a model of gastric mucosa exposed to stress, significant upregulation of PPAR- $\gamma$ at the protein level has been reported [178]; in this case, pretreatment with EcN attenuated the acute gastric mucosal lesions induced by stress through anti-inflammatory actions, induction of protective factors such as ghrelin and HSP70 synthesis in the gastric mucosa, and the enhancement of gastric microcirculation. These beneficial effects were accompanied by the decrease in PPAR$\gamma$ expression [178].

5.3. Compound VSL3. Compound VSL3 is a biotherapeutic agent (VSL Pharmaceuticals) formulated with of eight strains of bacteria (Lactobacillus acidophilus MB 443, Lactobacillus delbrueckii subsp. bulgaricus MB 453, Lactobacillus casei MB 451, Lactobacillus plantarum MB 452, Bifidobacterium longum Y10, Bifidobacterium infantis Y1, Bifidobacterium breve Y8, and Streptococcus salivarius subsp. thermophilus MB 455). 
This probiotic intervention results in a site-specific reduction of inflammatory pathways with increased expression of mediators involved in PPAR signaling [179]. Its administration attenuated the development of signs and symptoms of colitis, reduced colonic expression of TNF- $\alpha$, Interleukin (IL)-6, and IFN- $\gamma$, and reserved colonic downregulation of PPAR- $\gamma$, PXR, and FXR caused by a TNBS model of induced colitis [24].

Mesenteric adipose tissue from rodent colitis (TNBStreated animals) and Crohn's disease is metabolically active and shows inflammation-driven regulation of PPAR- $\gamma$, FXR, leptin, and adiponectin. The VSL3 probiotic prevents and corrects this inflammation-driven metabolic dysfunction [24]. VSL3 converts linoleic acid into CLA, in vitro and in vivo, inducing the up-regulation of PPAR- $\gamma$, a reduction in cancer cell viability, and the induction of apoptosis [180].

\section{PPAR-Gamma-Related Diseases That Can Be Complementarily Treated with Nutraceutics}

Obesity has led to alarming increases in the incidence of many chronic diseases, including type 2 diabetes and cardiovascular disease. Because overnutrition leads to obesity, manipulation of the dietary nutrient content is a logical means of alleviating this problem. In chronic disorders such as obesity and diabetes, mesenteric adipose tissue (MAT) hypertrophy is governed by the activation of PPAR family of nuclear receptors, mainly the $\alpha$ and $\gamma$ forms, FXR, liver-X receptor (LXR), and adipokines, which are well identified targets for medical interventions. In contrast, it remains unknown whether MAT could be modulated by pharmacological interventions in Crohn's disease [181].

The commensal gut microbiota has profound effects on the physiology of the host [182]. The intestinal microbiota may be exerting effects beyond the intestine and patients with chronic inflammatory disorders such as obesity and type I diabetes display an altered gut flora that may have a pathogenetic readout on the phenotype of these disorders [182-184].

Thirty years ago, it was largely appreciated that circulating levels of xeno- and endobiotics including bile acids, lipids, and metabolism intermediates are regulated by gut microbiota [185-187]. Thus, activation of PPAR- $\alpha$ and $-\gamma$, FXR, and LXR by lipid mediators, bile acids, and oxysterols not only modulates lipid/cholesterol metabolism, but also provides counter-regulatory signals for innate immunity cells $[7,8,24,188-190]$.

The immune system highly depends on a satisfactory supply of nutrients to function. Few studies have considered the immunomodulatory effects of oligosaccharides in humans and experimental animal models. Daily administration of different oligosaccharides significantly reduced damage associated with Crohn's disease, ulcerative colitis, and experimental colitis in rats [191-194].

6.1. Inflammatory Bowel Diseases (IBD). Inflammatory bowel disease (IBD) is a chronic, recurring immuno-inflammatory illness afflicting $0.1-24.5 / 100,000$ people worldwide with two clinical manifestations: Crohn's disease (CD) and Ulcerative colitis (UC) [195].

A growing body of evidence supports the notion that a mutual inhibition between pro-inflammatory mediators and nuclear receptors does exist in IBD [196, 197]. Evidence also suggests the potential therapeutic role and beneficial immunomodulatory effects of some commensal gut microbiota, such as probiotics, in the prevention or suitable treatment of gastrointestinal tract diseases [198] and mildto-moderate IBD by inducing immune homeostasis.

Clearly, PPAR- $\gamma$ represents a novel therapeutic target useful in reducing intestinal inflammation for the treatment of IBD $[22,199]$. Consistent with this view, Mencarelli et al. reported that acute TNBS colitis causes a robust decrease in the expression of several nuclear receptors including PPAR- $\gamma$, PXR, and FXR, and that these changes were antagonized by VSL\#3 cotreatment [24]. In addition, developing nutritional interventions against IBD, such as diets supplemented with CLA and n-3 PUFAs, is relevant [200] because this has been reported to ameliorate intestinal inflammation in animal models of IBD [201], an effect possibly related with bacterial recognition sites in Toll-like receptors (TLR) [202].

6.2. Crohn's Disease. This is a chronic and progressive inflammatory disorder of gastrointestinal tract [24]. Adipose tissue is increasingly identified as a major endocrine organ from which either metabolic or inflammatory signals propagate systemically, potentially modulating clinical features of Crohn's disease. Patients with Crohn's disease accumulate adipokine-releasing intra-abdominal fat from disease onset $[203,204]$, indicating that expansion of mesenteric fat depots may be an important source of inflammatory mediators in IBD [205]. An abnormal expression of PPAR- $\gamma$ has been reported in the MAT of patients with Crohn's disease [203].

Present results and previous data demonstrate that FXR exercises anti-inflammatory activity in rodent models of colitis [185] while promoting a less activated phenotype in adipose tissue [10], suggesting a potential therapeutic role for ligands of this nuclear receptor in the treatment of inflammation-driven activation of adipose tissue in Crohn's disease [24].

In conclusion, it has been shown that colonic inflammation regulates the expression of several nuclear receptors in MAT in a model of colitis and in patients with Crohn's disease. MAT activation could contribute to inflammationdriven immune and metabolic dysfunction in these patients by generating a subset of pro-inflammatory mediators and modulating the expression of several nuclear receptors. Whether PPAR- $\gamma$ expression is causal to susceptibility and/or pivotal in modulating adaptive immunity remains under investigation. These effects are counter-regulated by changing the composition of enteric flora with a probiotic [24].

6.3. Cardiac Disease. Activation of PPAR- $\alpha$ and $-\gamma$ by CLA prevents cardiac hypertrophy through activation of the diacyl glycerol kinase-zeta (DGK- $\zeta$ ) and subsequent inhibition of the protein kinase C-epsilon (PKC- $\varepsilon$ ) pathway. These findings provide novel support for the role of PUFAs as 
cardioprotective dietary elements. At a time when the prevention of hypertrophy is viewed as a promising therapeutic target [206] and $44 \%$ of patients with heart failure resort to nutrition-based therapies [207], this study may have important implications for effective nutritional intervention toward the prevention of cardiac disease. Finally, evidence from a clinical study indicate that dietary intake of omega3 fatty acids, particularly the DHA and EPA found in fatty fish or fish-oil supplements, reduces the risk of CVD [208].

\section{Concluding Remarks}

Despite the great potential benefits that nutraceutics are able to provide, one must be careful when consuming botanical and dietary supplements with anti-inflammatory and antioxidant properties when one is at risk for microbial infections. In vivo, the outcome of an infection is determined by a balance between means of host-immune defense versus those of the parasite, and antioxidants and anti-inflammatories may weaken immune defense and exacerbate the infection. Furthermore, the high prevalence of dietary supplements does not ensure that the nutrient intake of supplements would be the same among all of their consumers. The nutrient intake from dietary supplements varies in terms of the composition of the supplements. Therefore, it is urgent to meet nutrient needs by consuming foods that provide a well-balanced, nutrient-dense diet.

It is also important to engage in different types of evidence in support of the health benefits of natural products. Epidemiological information may offer the first suggestion that certain natural products, in the diets of specific populations, may exert an influence on the course of chronic diseases, such as obesity and some of its concomitant complications, such as cardiovascular diseases, diabetes, and cancer. Although the intake of certain dietary compounds indicate differences in the prevalence of some pathologies in specific groups, it does not prove that supplementation with these compounds could change the course of the pathologies. Genetic and environmental factors may all contribute to the final effects observed in a studied population.

In this paper, we carried out a detailed approach on the mechanistic and molecular interaction of nutraceutics and PPAR- $\gamma$, which has been identified as one of the major regulators of adipogenesis at a cellular level and a master regulator of energetic homeostasis. Because the use of synthetic PPAR- $\gamma$ agonists has been associated with an increased risk of cardiovascular ischemic events, natural PPAR- $\gamma$ ligands have been shown to ameliorate obesityrelated disorders and certain inflammatory diseases. Some of these agonists could activate both PPAR- $\alpha$ and PPAR$\gamma$ (dual PPAR- $\alpha /$ PPAR- $\gamma$ agonists), which might be even more effective. However, additional, extensive research of nutraceutics and their potential ability to modulate PPAR$\gamma$ in strengthening the inflammatory response network requires further study in the future. Unfortunately, there continue to be few clinical trials on these compounds and some evidences lack the molecular mechanisms. The group of evidences indicates that the effect of molecular interactions will also depend on the model studied in the laboratory. In vivo and in vitro assays have documented the biological effects on adipogenesis, inflammation, carcinogenesis, and so forth. However, additional studies should be conducted in PPAR- $\gamma$ conditional mice in which the effects of nutraceutics on adipose tissues the hyperplasia and hypertrophy, adipogenetic genes modulation, and inflammatory biomarkers can be directly observed and studied.

In conclusion, although more experimental work is required to evaluate their full potential in humans, especially in terms of safety, PPAR natural agonists nonetheless represent a promising strategy for mitigating obesity-related disorders and some inflammatory diseases, reducing the side effects exhibited by the commonly used pharmacological drugs. However, more randomized controlled trials are needed for nutraceutics that, in agreement with epidemiological and mechanistic evidence assays, could be good candidates for or against a specific pathology. Additionally, surprising results of increased disease risk with the consumption of some natural products have been found. Therefore, unless safety profiles for nutraceutical supplements in humans are available, caution should be used in their long-term use as PPAR- $\gamma$ modulators.

\section{Abbreviations}

$\begin{array}{ll}\text { PPAR: } & \text { Peroxisome proliferator-activated receptor } \\ \text { NASH: } & \text { Nonalcoholic steatohepatitis } \\ \text { RXR: } & \text { Retinoid-X receptor } \\ \text { FXR: } & \text { Farnesoid-X receptor } \\ \text { LXR: } & \text { Liver-X-receptor } \\ \text { FO: } & \text { Fish oil } \\ \text { LPL: } & \text { Lipoptrotein lipase } \\ \text { NF- } \kappa \text { B: } & \text { Nuclear factor- } \kappa \text { B } \\ \text { iNOS: } & \text { Inducible nitric oxide synthase } \\ \text { CLA: } & \text { Conjugated linoleic acid } \\ \text { N-3 PUFAs: } & \text { Polyunsaturated fatty acids } \\ \text { EPA: } & \text { Eicosapentaenoic acid } \\ \text { DHA: } & \text { Docosahexaenoic acid } \\ \text { BC: } & \quad \beta \text {-carotene } \\ \text { RA: } & \text { Retinoic acid } \\ \text { BL: } & \text { Banana lectin } \\ \text { GL: } & \text { Garlic lectin } \\ \text { FOS: } & \text { Fructooligosaccharides } \\ \text { MAT: } & \text { Mesenteric adipose tissue } \\ \text { IBD: } & \text { Inflammatory bowel disease } \\ \text { CD: } & \text { Crohn's disease } \\ \text { UC: } & \text { Ulcerative colitis. } \\ & \end{array}$

\section{Acknowledgments}

This work was partially supported by CONACYT grants, 2012-180268 to A. E. R. Mayorquín, 295457 to S. Q. Fabián, FOMIX-HGO-2008-C01-97092 to A. L. M. Aguirre, and PROMEP/103.5/08/2919 to R. I. López-Roa. Because of length restriction, in some cases either a single paper or a review is cited. To authors whose works we have not reviewed, to those whose papers have not received the 
emphasis that they deserve, and to those authors whose work has not been appropriately cited because of the limitations of the space and/or our knowledge, we apologize.

\section{References}

[1] A. Tenenbaum, E. Z. Fisman, and M. Motro, "Metabolic syndrome and type 2 diabetes mellitus: focus on peroxisome proliferator activated receptors (PPAR)," Cardiovascular Diabetology, vol. 2, article 4, 2003.

[2] B. Desvergne, L. Michalik, and W. Wahli, "Be fit or be sick: peroxisome proliferator-activated receptors are down the road," Molecular Endocrinology, vol. 18, no. 6, pp. 13211332, 2004.

[3] J. N. Feige, L. Gelman, L. Michalik, B. Desvergne, and W. Wahli, "From molecular action to physiological outputs: peroxisome proliferator-activated receptors are nuclear receptors at the crossroads of key cellular functions," Progress in Lipid Research, vol. 45, no. 2, pp. 120-159, 2006.

[4] P. A. Grimaldi, "Peroxisome proliferator-activated receptors as sensors of fatty acids and derivatives," Cellular and Molecular Life Sciences, vol. 64, no. 19-20, pp. 2459-2464, 2007.

[5] P. Tontonoz, S. Singer, B. M. Forman et al., "Terminal differentiation of human liposarcoma cells induced by ligands for peroxisome proliferator-activated receptor $\gamma$ and the retinoid X receptor," Proceedings of the National Academy of Sciences of the United States of America, vol. 94, no. 1, pp. 237-241, 1997.

[6] K. Yoshizawa, D. P. Cioca, S. Kawa, E. Tanaka, and K. Kiyosawa, "Peroxisome proliferator-activated receptor $\gamma$ ligand troglitazone induces cell cycle arrest and apoptosis of hepatocellular carcinoma cell lines," Cancer, vol. 95, no. 10, pp. 2243-2251, 2002.

[7] C. Jiang, A. T. Ting, and B. Seed, "PPAR- $y$ agonists inhibit production of monocyte inflammatory cytokines," Nature, vol. 391, no. 6662, pp. 82-86, 1998.

[8] M. Ricote, A. C. Li, T. M. Willson, C. J. Kelly, and C. K. Glass, "The peroxisome proliferator-activated receptor- $\gamma$ is a negative regulator of macrophage activation," Nature, vol. 391, no. 6662, pp. 79-82, 1998.

[9] J. J. Nolan, B. Ludvik, P. Beerdsen, M. Joyce, and J. Olefsky, "Improvement in glucose tolerance and insulin resistance in obese subjects treated with troglitazone," The New England Journal of Medicine, vol. 331, no. 18, pp. 1188-1193, 1994.

[10] G. Rizzo, M. Disante, A. Mencarelli et al., "The farnesoid $\mathrm{X}$ receptor promotes adipocyte differentiation and regulates adipose cell function in vivo," Molecular Pharmacology, vol. 70, no. 4, pp. 1164-1173, 2006.

[11] M. Abdelkarim, S. Caron, C. Duhem et al., "The farnesoid X receptor regulates adipocyte differentiation and function by promoting peroxisome proliferator-activated receptor- $\gamma$ and interfering with the $\mathrm{Wnt} / \beta$-catenin pathways," The Journal of Biological Chemistry, vol. 285, no. 47, pp. 36759-36767, 2010.

[12] R. P. Brun, J. B. Kim, E. Hu, and B. M. Spiegelman, "Peroxisome proliferator-activated receptor gamma and the control of adipogenesis," Current Opinion in Lipidology, vol. 8, no. 4, pp. 212-218, 1997.

[13] M. I. Lefterova and M. A. Lazar, "New developments in adipogenesis," Trends in Endocrinology and Metabolism, vol. 20, no. 3, pp. 107-114, 2009.

[14] S. M. Rangwala and M. A. Lazar, "Transcriptional control of adipogenesis," Annual Review of Nutrition, vol. 20, pp. 535559,2000
[15] E. D. Rosen and B. M. Spiegelman, "Molecular regulation of adipogenesis," Annual Review of Cell and Developmental Biology, vol. 16, pp. 145-171, 2000.

[16] P. G. P. Martin, H. Guillou, F. Lasserre et al., "Novel aspects of PPAR $\alpha$-mediated regulation of lipid and xenobiotic metabolism revealed through a nutrigenomic study," Hepatology, vol. 45, no. 3, pp. 767-777, 2007.

[17] N. Suh, Y. Wang, C. R. Williams et al., "A new ligand for the peroxisome proliferator-activated receptor- $\gamma$ (PPAR$\gamma$ ), GW7845, inhibits rat mammary carcinogenesis," Cancer Research, vol. 59, no. 22, pp. 5671-5673, 1999.

[18] P. H. Brown and S. M. Lippman, "Chemoprevention of breast cancer," Breast Cancer Research and Treatment, vol. 62, no. 1, pp. 1-17, 2000.

[19] S. I. Anghel and W. Wahli, "Fat poetry: a kingdom for PPAR $y$," Cell Research, vol. 17, no. 6, pp. 486-511, 2007.

[20] M. Gurnell, “'Striking the right balance' in targeting PPAR $\gamma$ in the metabolic syndrome: novel insights from human genetic studies," PPAR Research, Article ID 83593, 2007.

[21] E. E. Kershaw and J. S. Flier, "Adipose tissue as an endocrine organ," Journal of Clinical Endocrinology and Metabolism, vol. 89, no. 6, pp. 2548-2556, 2004.

[22] G. D. Wu, "Is there a role for PPAR $\gamma$ in IBD? Yes, no, maybe," Gastroenterology, vol. 124, no. 5, pp. 1538-1542, 2003.

[23] R. W. Nesto, D. Bell, R. O. Bonow et al., "Thiazolidinedione use, fluid retention, and congestive heart failure: a consensus statement from the American Heart Association and American Diabetes Association," Diabetes Care, vol. 27, no. 1, pp. 256-263, 2004.

[24] A. Mencarelli, E. Distrutti, B. Renga et al., "Probiotics modulate intestinal expression of nuclear receptor and provide Counter-Regulatory signals to Inflammation-Driven adipose tissue activation," PLoS ONE, vol. 6, no. 7, article e22978, 2011.

[25] N. Cho and Y. Momose, "Peroxisome proliferator-activated receptor $\gamma$ agonists as insulin sensitizers: from the discovery to recent progress," Current Topics in Medicinal Chemistry, vol. 8, no. 17, pp. 1483-1507, 2008.

[26] C. V. Rizos, M. S. Elisaf, D. P. Mikhailidis, and E. N. Liberopoulos, "How safe is the use of thiazolidinediones in clinical practice?" Expert Opinion on Drug Safety, vol. 8, no. 1, pp. 15-32, 2009.

[27] D. J. Newman and G. M. Cragg, "Natural products as sources of new drugs over the 30 years from 1981 to 2010," Journal of Natural Products, vol. 75, no. 3, pp. 311-335, 2012.

[28] O. Rau, M. Wurglics, A. Paulke et al., "Carnosic acid and carnosol, phenolic diterpene compounds of the labiate herbs rosemary and sage, are activators of the human peroxisome proliferator-activated receptor gamma," Planta Medica, vol. 72, no. 10, pp. 881-887, 2006.

[29] G. Paliyath, M. Bakovic K, and Shetty, Functional Foods, Nutraceuticals, and Degenerative Disease Prevention, John Wiley \& Sons, 1st edition, 2011.

[30] D. W. Haslam and W. P. T. James, "Obesity," The Lancet, vol. 366, no. 9492, pp. 1197-1209, 2005.

[31] A. T. Diplock, P. J. Aggett, M. Ashwell, F. Bornet, E. B. Fern, and M. B. Roberfroid, "Scientific concepts of functional foods in Europe: consensus document," British Journal of Nutrition, vol. 81, no. 1, pp. I-27, 1999.

[32] M. Subirade, Report on Functional Foods, Food Quality and Standards Service (AGNS) and Food and Agriculture Organization of the United Nations (FAOS), Rome, Italy, 2007.

[33] M. J. Amiot and D. Lairon, "Fruit and vegetables, cardiovascular disease, diabetes and obesity," in Improving the 
Health-Promoting Properties of Fruit and Vegetable Products, F. A. Tomás-Barberán and M. I. Gil, Eds., pp. 95-118, CRC Press, Boca Raton, Fla, USA, 2010.

[34] J. Von Lintig, "Colors with functions: elucidating the biochemical and molecular basis of carotenoid metabolism," Annual Review of Nutrition, vol. 30, pp. 35-56, 2010.

[35] O. P. García, K. Z. Long, and J. L. Rosado, "Impact of micronutrient deficiencies on obesity," Nutrition Reviews, vol. 67, no. 10, pp. 559-572, 2009.

[36] E. S. Ford, J. C. Will, B. A. Bowman, and K. M. V. Narayan, "Diabetes mellitus and serum carotenoids: findings from the Third National Health and Nutrition Examination Survey," American Journal of Epidemiology, vol. 149, no. 2, pp. 168176, 1999.

[37] K. Ylönen, G. Alfthan, L. Groop, C. Saloranta, A. Aro, and S. M. Virtanen, "Dietary intakes and plasma concentrations of carotenoids and tocopherols in relation to glucose metabolism in subjects at high risk of type 2 diabetes: the Botnia Dietary Study," American Journal of Clinical Nutrition, vol. 77, no. 6, pp. 1434-1441, 2003.

[38] T. Coyne, T. I. Ibiebele, P. D. Baade et al., "Diabetes mellitus and serum carotenoids: findings of a populationbased study in Queensland, Australia," American Journal of Clinical Nutrition, vol. 82, no. 3, pp. 685-693, 2005.

[39] V. Ramakrishna and R. Jailkhani, "Oxidative stress in noninsulin-dependent diabetes mellitus (NIDDM) patients," Acta Diabetologica, vol. 45, no. 1, pp. 41-46, 2008.

[40] T. L. Burrows, J. M. Warren, K. Colyvas, M. L. Garg, and C. E. Collins, "Validation of overweight children's fruit and vegetable intake using plasma carotenoids," Obesity, vol. 17, no. 1, pp. 162-168, 2009.

[41] S. Hessel, A. Eichinger, A. Isken et al., "CMO1 deficiency abolishes vitamin a production from $\beta$-carotene and alters lipid metabolism in mice," The Journal of Biological Chemistry, vol. 282, no. 46, pp. 33553-33561, 2007.

[42] A. Boulanger, P. McLemore, N. G. Copeland et al., "Identification of beta-carotene 15, 159-monooxygenase as a peroxisome proliferator-activated receptor target gene," The FASEB Journal, vol. 17, no. 10, pp. 1304-1306, 2003.

[43] X. Gong, S. W. Tsai, B. Yan, and L. P. Rubin, "Cooperation between MEF2 and PPAR $\gamma$ in human intestinal $\beta, \beta$-carotene 15, 159-monooxygenase gene expression," BMC Molecular Biology, vol. 7, article 7, 2006.

[44] G. P. Lobo, J. Amengual, H. N. M. Li et al., " $\beta, \beta$-carotene decreases peroxisome proliferator receptor $\gamma$ activity and reduces lipid storage capacity of adipocytes in a $\beta, \beta$-carotene oxygenase 1-dependent manner," The Journal of Biological Chemistry, vol. 285, no. 36, pp. 27891-27899, 2010.

[45] O. Ziouzenkova, G. Orasanu, M. Sharlach et al., "Retinaldehyde represses adipogenesis and diet-induced obesity," Nature Medicine, vol. 13, no. 6, pp. 695-702, 2007.

[46] O. Ziouzenkova, G. Orasanu, G. Sukhova et al., "Asymmetric cleavage of $\beta$-carotene yields a transcriptional repressor of retinoid X receptor and peroxisome proliferator-activated receptor responses," Molecular Endocrinology, vol. 21, no. 1, pp. 77-88, 2007.

[47] W. L. Stone, K. Krishnan, S. E. Campbell, M. Qui, S. G. Whaley, and H. Yang, "Tocopherols and the treatment of colon cancer," Annals of the New York Academy of Sciences, vol. 1031, pp. 223-233, 2004.

[48] S. E. Campbell, W. L. Stone, S. G. Whaley, M. Qui, and K. Krishnan, "Gamma $(\gamma)$ tocopherol upregulates peroxisome proliferator activated receptor (PPAR) gamma $(\gamma)$ expression in SW 480 human colon cancer cell lines," BMC Cancer, vol. 3 , article 25, 2003.

[49] D. C. Berry and N. Noy, "All-trans-retinoic acid represses obesity and insulin resistance by activating both peroxisome proliferation-activated receptor $\beta / \delta$ and retinoic acid receptor," Molecular and Cellular Biology, vol. 29, no. 12, pp. 32863296, 2009.

[50] P. M. Kris-Etherton, W. S. Harris, and L. J. Appel, "Fish consumption, fish oil, omega-3 fatty acids, and cardiovascular disease," Circulation, vol. 106, no. 21, pp. 2747-2757, 2002.

[51] P. Flachs, V. Mohamed-Ali, O. Horakova et al., "Polyunsaturated fatty acids of marine origin induce adiponectin in mice fed a high-fat diet," Diabetologia, vol. 49, no. 2, pp. 394-397, 2006.

[52] D. Hwang, "Fatty acids and immune responses-a new perspective in searching for clues to mechanism," Annual Review of Nutrition, vol. 20, pp. 431-456, 2000.

[53] M. A. Belury, "Dietary conjugated linoleic acid in health: physiological effects and mechanisms of action," Annual Review of Nutrition, vol. 22, pp. 505-531, 2002.

[54] O. Mezei, W. J. Banz, R. W. Steger, M. R. Peluso, T. A. Winters, and N. Shay, "Soy isoflavones exert antidiabetic and hypolipidemic effects through the PPAR pathways in obese Zucker rats and murine RAW 264.7 cells," Journal of Nutrition, vol. 133, no. 5, pp. 1238-1243, 2003.

[55] A. S. Wilkinson, G. R. Monteith, P. N. Shaw, C. N. Lin, M. J. Gidley, and S. J. Roberts-Thomson, "Effects of the mango components mangiferin and quercetin and the putative mangiferin metabolite norathyriol on the transactivation of peroxisome proliterator-activated receptor isoforms," Journal of Agricultural and Food Chemistry, vol. 56, no. 9, pp. 30373042, 2008.

[56] T. Sangeetha and S. D. Quine, "Protective effect of S-allyl cysteine sulphoxide (alliin) on glycoproteins and hematology in isoproterenol induced myocardial infarction in male Wistar rats," Journal of Applied Toxicology, vol. 28, no. 5, pp. 710-716, 2008.

[57] G. J. Kelloff, C. W. Boone, J. A. Crowell, V. E. Steele, R. Lubet, and C. C. Sigman, "Chemopreventive drug development: perspectives and progress," Cancer Epidemiology Biomarkers and Prevention, vol. 3, no. 1, pp. 85-98, 1994.

[58] S. Ulrich, S. M. Loitsch, O. Rau et al., "Peroxisome proliferator-activated receptor $\gamma$ as a molecular target of resveratrol-induced modulation of polyamine metabolism," Cancer Research, vol. 66, no. 14, pp. 7348-7354, 2006.

[59] G. Alberdi, V. M. Rodríguez, J. Miranda et al., "Changes in white adipose tissue metabolism induced by resveratrol in rats," Nutrition and Metabolism, vol. 8, no. 1, article 29, 2011.

[60] I. Lee, H. Kim, U. Youn et al., "Effect of lanostane triterpenes from the fruiting bodies of Ganoderma lucidum on adipocyte differentiation in 3T3-L1 cells," Planta Medica, vol. 76, no. 14, pp. 1558-1563, 2010.

[61] N. M. Delzenne and C. M. Williams, "Prebiotics and lipid metabolism," Current Opinion in Lipidology, vol. 13, no. 1, pp. 61-67, 2002.

[62] D. Czerucka, S. Dahan, B. Mograbi, B. Rossi, and P. Rampal, "Saccharomyces boulardii preserves the barrier function and modulates the signal transduction pathway induced in enteropathogenic Escherichia coli-infected T84 cells," Infection and Immunity, vol. 68, no. 10, pp. 5998-6004, 2000.

[63] A. C. P. Rodrigues, D. C. Cara, S. H. G. G. Fretez et al., "Saccharomyces boulardii stimulates sIgA production and the phagocytic system of gnotobiotic mice," Journal of Applied Microbiology, vol. 89, no. 3, pp. 404-414, 2000. 
[64] A. Eroglu, D. P. Hruszkewycz, R. W. Curley, and E. H. Harrison, "The eccentric cleavage product of $\beta$-carotene, $\beta$ apo-13-carotenone, functions as an antagonist of $\operatorname{RXR} \alpha$," Archives of Biochemistry and Biophysics, vol. 504, no. 1, pp. 11-16, 2010.

[65] J. Amengual, E. Gouranton, Y. G. J. van Helden et al., "Betacarotene reduces body adiposity of mice via BCMO1," PLoS ONE, vol. 6, no. 6, Article ID e20644, 2011.

[66] X. Wang and P. J. Quinn, "Vitamin E and its function in membranes," Progress in Lipid Research, vol. 38, no. 4, pp. 309-336, 1999.

[67] C. Constantinou, A. Papas, and A. I. Constantinou, "Vitamin $\mathrm{E}$ and cancer: an insight into the anticancer activities of vitamin $\mathrm{E}$ isomers and analogs," International Journal of Cancer, vol. 123, no. 4, pp. 739-752, 2008.

[68] M. G. Traber, "Vitamin E regulatory mechanisms," Annual Review of Nutrition, vol. 27, pp. 347-362, 2007.

[69] M. G. Traber, "Vitamin E," in Modern Nutrition in Health and Disease, ShilsME, ShikeM, A. C. Ross, B. Caballero, and R. J. Cousins, Eds., pp. 396-411, Lippincott Williams and Wilkins, Baltimore, Md, USA, 10th edition, 2006.

[70] M. H. Fenner and E. Elstner, "Peroxisome proliferatoractivated receptor- $\gamma$ ligands for the treatment of breast cancer," Expert Opinion on Investigational Drugs, vol. 14, no. 6, pp. 557-568, 2005.

[71] J. L. Hong, J. Ju, S. Paul et al., "Mixed tocopherols prevent mammary tumorigenesis by inhibiting estrogen action and activating PPAR- $\gamma$," Clinical Cancer Research, vol. 15, no. 12, pp. 4242-4249, 2009.

[72] A. A. Qureshi, X. Tan, J. C. Reis et al., "Inhibition of nitric oxide in LPS-stimulated macrophages of young and senescent mice by $\delta$-tocotrienol and quercetin," Lipids in Health and Disease, vol. 10, p. 239, 2011.

[73] A. A. Qureshi, J. C. Reis, N. Qureshi, C. J. Papasian, D. C. Morrison, and D. M. Schaefer, " $\delta$-Tocotrienol and quercetin reduce serum levels of nitric oxide and lipid parameters in female chickens," Lipids in Health and Disease, vol. 10, article 39, 2011.

[74] H. Uto-Kondo, R. Ohmori, C. Kiyose et al., "Tocotrienol suppresses adipocyte differentiation and Akt phosphorylation in 3T3-L1 preadipocytes," Journal of Nutrition, vol. 139, no. 1, pp. 51-57, 2009.

[75] W. Kuri Harcuch, "Differentiation of 3T3-F442A cells into adipocytes is inhibited by retinoic acid," Differentiation, vol. 23, no. 2, pp. 164-169, 1982.

[76] E. J. Schwarz, M. J. Reginato, D. Shao, S. L. Krakow, and M. A. Lazar, "Retinoic acid blocks adipogenesis by inhibiting $\mathrm{C} / \mathrm{EBP} \beta$-mediated transcription," Molecular and Cellular Biology, vol. 17, no. 3, pp. 1552-1561, 1997.

[77] J. Ribot, F. Felipe, M. L. Bonet, and A. Palou, "Changes of adiposity in response to vitamin A status correlate with changes of PPAR $\gamma 2$ expression," Obesity Research, vol. 9, no. 8, pp. 500-509, 2001.

[78] K. Hollung, C. P. Rise, C. A. Drevon, and J. E. Reseland, "Tissue-specific regulation of leptin expression and secretion by all-trans retinoic acid," Journal of Cellular Biochemistry, vol. 92, no. 2, pp. 307-315, 2004.

[79] F. Felipe, M. L. Bonet, J. Ribot, and A. Palou, "Modulation of resistin expression by retinoic acid and vitamin A status," Diabetes, vol. 53, no. 4, pp. 882-889, 2004.

[80] F. Felipe, J. Mercader, J. Ribot, A. Palou, and M. L. Bonet, "Effects of retinoic acid administration and dietary vitamin A supplementation on leptin expression in mice: lack of correlation with changes of adipose tissue mass and food intake," Biochimica et Biophysica Acta, vol. 1740, no. 2, pp. 258-265, 2005.

[81] J. Mercader, N. Granados, M. L. Bonet, and A. Palou, "Alltrans retinoic acid decreases murine adipose retinol binding protein 4 production," Cellular Physiology and Biochemistry, vol. 22, no. 1-4, pp. 363-372, 2008.

[82] M. Petkovich, N. J. Brand, A. Krust, and P. Chambon, "A human retinoic acid receptor which belongs to the family of nuclear receptors," Nature, vol. 330, no. 6147, pp. 444-450, 1987.

[83] A. Aranda and A. Pascual, "Nuclear hormone receptors and gene expression," Physiological Reviews, vol. 81, no. 3, pp. 1269-1304, 2001.

[84] N. Shaw, M. Elholm, and N. Noy, "Retinoic acid is a high affinity selective ligand for the peroxisome proliferatoractivated receptor $\beta / \delta$," The Journal of Biological Chemistry, vol. 278, no. 43, pp. 41589-41592, 2003.

[85] Y. Hida, T. Kawada, S. Kayahashi, T. Ishihara, and T. Fushiki, "Counteraction of retinoic acid and 1,25-dihydroxyvitamin D3 on up- regulation of adipocyte differentiation with PPAR $\gamma$ ligand, an antidiabetic thiazolidinedione, in 3T3-L1 cells," Life Sciences, vol. 62, no. 14, pp. 205-211, 1998.

[86] G. Duque, M. Macoritto, and R. Kremer, "1,25(OH)2D3 inhibits bone marrow adipogenesis in senescence accelerated mice (SAM-P/6) by decreasing the expression of peroxisome proliferator-activated receptor gamma $2(\operatorname{PPAR} \gamma 2)$," Experimental Gerontology, vol. 39, no. 3, pp. 333-338, 2004.

[87] P. Yaqoob and P. C. Calder, "N-3 polyunsaturated fatty acids and inflammation in the arterial wall," European Journal of Medical Research, vol. 8, no. 8, pp. 337-354, 2003.

[88] D. Sun, A. Krishnan, K. Zaman, R. Lawrence, A. Bhattacharya, and G. Fernandes, "Dietary n-3 fatty acids decrease osteoclastogenesis and loss of bone mass in ovariectomized Mice," Journal of Bone and Mineral Research, vol. 18, no. 7, pp. 1206-1216, 2003.

[89] T. A. Mori, D. Q. Bao, V. Burke, I. B. Puddey, and L. J. Beilin, "Docosahexaenoic acid but not eicosapentaenoic acid lowers ambulatory blood pressure and heart rate in humans," Hypertension, vol. 34, no. 2, pp. 253-260, 1999.

[90] V. M. Montori, A. Farmer, P. C. Wollan, and S. F. Dinneen, "Fish oil supplementation in type 2 diabetes: a quantitative systematic review," Diabetes Care, vol. 23, no. 9, pp. 14071415, 2000.

[91] L. H. Storlien, E. W. Kraegen, D. J. Chisholm et al., "Fish oil prevents insulin resistance induced by high-fat feeding in rats," Science, vol. 237, no. 4817, pp. 885-888, 1987.

[92] S. Neschen, K. Morino, J. Dong et al., "n-3 fatty acids preserve insulin sensitivity in vivo in a peroxisome proliferatoractivated receptor- $\alpha$-dependent manner," Diabetes, vol. 56, no. 4, pp. 1034-1041, 2007.

[93] P. C. Calder, "n-3 Polyunsaturated fatty acids, inflammation, and inflammatory diseases," American Journal of Clinical Nutrition, vol. 83, no. 6, pp. 1505S-1519S, 2006.

[94] W. E. Connor, "Importance of n-3 fatty acids in health and disease," American Journal of Clinical Nutrition, vol. 71, no. 1, pp. 171S-175S, 2000.

[95] M. K. Duda, K. M. O'Shea, B. Lei et al., “Dietary supplementation with $\omega$-3 PUFA increases adiponectin and attenuates ventricular remodeling and dysfunction with pressure overload," Cardiovascular Research, vol. 76, no. 2, pp. 303-310, 2007.

[96] M. J. Puglisi, A. H. Hasty, and V. Saraswathi, "The role of adipose tissue in mediating the beneficial effects of dietary 
fish oil," Journal of Nutritional Biochemistry, vol. 22, no. 2, pp. 101-108, 2011.

[97] K. Yamamoto, T. Itoh, D. Abe et al., "Identification of putative metabolites of docosahexaenoic acid as potent PPAR $\gamma$ agonists and antidiabetic agents," Bioorganic and Medicinal Chemistry Letters, vol. 15, no. 3, pp. 517-522, 2005.

[98] D. B. Jump, "N-3 polyunsaturated fatty acid regulation of hepatic gene transcription," Current Opinion in Lipidology, vol. 19, no. 3, pp. 242-247, 2008.

[99] A. González-Périz, R. Horrillo, N. Ferré et al., "Obesityinduced insulin resistance and hepatic steatosis are alleviated by $\omega-3$ fatty acids: a role for resolvins and protectins," FASEB Journal, vol. 23, no. 6, pp. 1946-1957, 2009.

[100] O. A. B. S. M. Gani, "Are fish oil omega-3 long-chain fatty acids and their derivatives peroxisome proliferator-activated receptor agonists?" Cardiovascular Diabetology, vol. 7, article 6, 2008.

[101] A. M. Turpeinen, M. Mutanen, A. Aro et al., "Bioconversion of vaccenic acid to conjugated linoleic acid in humans," American Journal of Clinical Nutrition, vol. 76, no. 3, pp. 504510, 2002.

[102] J. Bassaganya-Riera, R. Hontecillas, and D. C. Beitz, "Colonic anti-inflammatory mechanisms of conjugated linoleic acid," Clinical Nutrition, vol. 21, no. 6, pp. 451-459, 2002.

[103] S. Y. Moya-Camarena, J. P. Vanden Heuvel, S. G. Blanchard, L. A. Leesnitzer, and M. A. Belury, "Conjugated linoleic acid is a potent naturally occurring ligand and activator of PPAR $\alpha$, Journal of Lipid Research, vol. 40, no. 8, pp. 14261433, 1999.

[104] D. S. Kelley, P. C. Taylor, G. J. Nelson et al., "Docosahexaenoic acid ingestion inhibits natural killer cell activity and production of inflammatory mediators in young healthy men," Lipids, vol. 34, no. 4, pp. 317-324, 1999.

[105] S. Kew, E. S. Gibbons, F. Thies, G. P. McNeill, P. T. Quinlan, and P. C. Calder, "The effect of feeding structured triacylglycerols enriched in eicosapentaenoic or docosahexaenoic acids on murine splenocyte fatty acids composition and leucocyte phagocytosis," British Journal of Nutrition, vol. 90, no. 6, pp. 1071-1080, 2003.

[106] C. N. Serhan, C. B. Clish, J. Brannon, S. P. Colgan, N. Chiang, and K. Gronert, "Novel functional sets of lipidderived mediators with antiinflammatory actions generated from omega-3 fatty acids via cyclooxygenase 2-nonsteroidal antiinflammatory drugs and transcellular processing," Journal of Experimental Medicine, vol. 192, no. 8, pp. 1197-1204, 2000.

[107] A. Bhattacharya, J. Banu, M. Rahman, J. Causey, and G. Fernandes, "Biological effects of conjugated linoleic acids in health and disease," Journal of Nutritional Biochemistry, vol. 17, no. 12, pp. 789-810, 2006.

[108] C. P. Alibin, M. A. Kopilas, and H. D. I. Anderson, "Suppression of cardiac myocyte hypertrophy by conjugated linoleic acid: role of peroxisome proliferator-activated receptors $\alpha$ and $\gamma$," The Journal of Biological Chemistry, vol. 283, no. 16, pp. 10707-10715, 2008.

[109] Y. W. Wang and P. J. H. Jones, "Conjugated linoleic acid and obesity control: efficacy and mechanisms," International Journal of Obesity, vol. 28, no. 8, pp. 941-955, 2004.

[110] L. D. Whigham, A. C. Watras, and D. A. Schoeller, "Efficacy of conjugated linoleic acid for reducing fat mass: a metaanalysis in humans," American Journal of Clinical Nutrition, vol. 85, no. 5, pp. 1203-1211, 2007.
[111] K. W. J. Wahle, S. D. Heys, and D. Rotondo, "Conjugated linoleic acids: are they beneficial or detrimental to health?" Progress in Lipid Research, vol. 43, no. 6, pp. 553-587, 2004.

[112] N. Tsuboyama-Kasaoka, M. Takahashi, K. Tanemura et al., "Conjugated linoleic acid supplementation reduces adipose tissue by apoptosis and develops lipodystrophy in mice," Diabetes, vol. 49, no. 9, pp. 1534-1542, 2000.

[113] F. Moloney, T. P. Yeow, A. Mullen, J. J. Nolan, and H. M. Roche, "Conjugated linoleic acid supplementation, insulin sensitivity, and lipoprotein metabolism in patients with type 2 diabetes mellitus," American Journal of Clinical Nutrition, vol. 80, no. 4, pp. 887-895, 2004.

[114] U. Risérus, P. Arner, K. Brismar, and B. Vessby, "Treatment with dietary trans10cis12 conjugated linoleic acid causes isomer-specific insulin resistance in obese men with the metabolic syndrome," Diabetes Care, vol. 25, no. 9, pp. 15161521, 2002.

[115] U. Risérus, B. Vessby, P. Arner, and B. Zethelius, "Supplementation with trans10cis12-conjugated linoleic acid induces hyperproinsulinaemia in obese men: close association with impaired insulin sensitivity," Diabetologia, vol. 47, no. 6, pp. 1016-1019, 2004.

[116] J. P. DeLany, F. Blohm, A. A. Truett, J. A. Scimeca, and D. B. West, "Conjugated linoleic acid rapidly reduces body fat content in mice without affecting energy intake," American Journal of Physiology, vol. 276, no. 4, pp. R1172-R1179, 1999.

[117] H. Poirier, I. Niot, L. Clément, M. Guerre-Millo, and P. Besnard, "Development of conjugated linoleic acid (CLA)mediated lipoatrophic syndrome in the mouse," Biochimie, vol. 87, no. 1, pp. 73-79, 2005.

[118] G. V. Halade, M. M. Rahman, P. J. Williams, and G. Fernandes, "Combination of conjugated linoleic acid with fish oil prevents age-associated bone marrow adiposity in C57Bl/6J mice," Journal of Nutritional Biochemistry, vol. 22, no. 5, pp. 459-469, 2011.

[119] F. J. Pérez-Cano, C. Ramírez-Santana, M. Molero-Luís et al., "Mucosal IgA increase in rats by continuous CLA feeding during suckling and early infancy," Journal of Lipid Research, vol. 50, no. 3, pp. 467-476, 2009.

[120] M. Hensler, K. Bardova, Z. M. Jilkova et al., "The inhibition of fat cell proliferation by n-3 fatty acids in dietary obese mice," Lipids in Health and Disease, vol. 10, p. 128, 2011.

[121] Z. C. Dang, V. Audinot, S. E. Papapoulos, J. A. Boutin, and C. W. G. M. Löwik, "PPAR $\gamma$ as a molecular target for the soy phytoestrogen genistein," The Journal of Biological Chemistry, vol. 278, no. 2, pp. 962-967, 2003.

[122] S. Kim, H. J. Shin, S. Y. Kim et al., "Genistein enhances expression of genes involved in fatty acid catabolism through activation of PPAR $\alpha$," Molecular and Cellular Endocrinology, vol. 220, no. 1-2, pp. 51-58, 2004.

[123] M. L. Ricketts, D. D. Moore, W. J. Banz, O. Mezei, and N. F. Shay, "Molecular mechanisms of action of the soy isoflavones includes activation of promiscuous nuclear receptors. A review," Journal of Nutritional Biochemistry, vol. 16, no. 6, pp. 321-330, 2005

[124] O. Mezei, Y. Li, E. Mullen, J. S. Ross-Viola, and N. F. Shay, "Dietary isoflavone supplementation modulates lipid metabolism via PPAR $\alpha$-dependent and -independent mechanisms," Physiological Genomics, vol. 26, no. 1, pp. 8-14, 2006.

[125] S. L. Yeh, C. L. Yeh, S. T. Chan, and C. H. Chuang, "Plasma rich in quercetin metabolites induces G2/M arrest by upregulating PPAR- expression in human A549 lung cancer cells," Planta Medica, vol. 77, no. 10, pp. 992-998, 2011. 
[126] M. Kobori, S. Masumoto, Y. Akimoto, and H. Oike, "Chronic dietary intake of quercetin alleviates hepatic fat accumulation associated with consumption of a Western-style diet in C57/BL6J mice," Molecular Nutrition and Food Research, vol. 55, no. 4, pp. 530-540, 2011.

[127] D. F. McMichael-Phillips, C. Harding, M. Morton et al., "Effects of soy-protein supplementation on epithelial proliferation in the histologically normal human breast," American Journal of Clinical Nutrition, vol. 68, no. 6, pp. 1431S-1435S, 1998.

[128] C. R. Sirtori, A. Arnoldi, and S. K. Johnson, "Phytoestrogens: end of a tale?" Annals of Medicine, vol. 37, no. 6, pp. 423-438, 2005.

[129] M. Bajaj, A. Hinge, L. S. Limaye, R. K. Gupta, A. Surolia, and V. P. Kale, "Mannose-binding dietary lectins induce adipogenic differentiation of the marrow-derived mesenchymal cells via an active insulin-like signaling mechanism," Glycobiology, vol. 21, no. 4, pp. 521-529, 2011.

[130] A. Hinge, M. Bajaj, L. Limaye, A. Surolia, and V. Kale, "Oral administration of insulin receptor-interacting lectins leads to an enhancement in the hematopoietic stem and progenitor cell pool of mice," Stem Cells and Development, vol. 19, no. 2, pp. 163-173, 2010.

[131] G. Hodge, S. Hodge, and P. Han, "Allium sativum (garlic) suppresses leukocyte inflammatory cytokine production in vitro: potential therapeutic use in the treatment of inflammatory bowel disease," Cytometry, vol. 48, no. 4, pp. 209-215, 2002.

[132] M. Iciek, I. Kwiecieri, and L. Włodek, "Biological properties of garlic and garlic-derived organosulfur compounds," Environmental and Molecular Mutagenesis, vol. 50, no. 3, pp. 247265, 2009.

[133] H. Chai, L. Wo, Y. Fu, T. Xie, Q. Wang, and L. Huang, "S-allylL-cysteine sulfoxide inhibits tumor necrosis factor-alpha induced monocyte adhesion and intercellular cell adhesion molecule-1 expression in human umbilical vein endothelial cells," Anatomical Record, vol. 293, no. 3, pp. 421-430, 2010.

[134] S. A. Nasim, B. Dhir, R. Kapoor et al., "Alliin obtained from leaf extract of garlic grown under in situ conditions possess higher therapeutic potency as analyzed in alloxan-induced diabetic rats," Pharmaceutical Biology, vol. 49, no. 4, pp. 416421, 2011.

[135] R. Apitz-Castro, J. J. Badimon, and L. Badimon, "Effect of ajoene, the major antiplatelet compound from garlic, on platelet thrombus formation," Thrombosis Research, vol. 68, no. 2, pp. 145-155, 1992.

[136] C. Egen-Schwind, R. Eckard, F. W. Jekat, and H. Winterhoff, "Pharmacokinetics of vinyldithiins, transformation products of allicin," Planta Medica, vol. 58, no. 1, pp. 8-13, 1992.

[137] M. Keophiphath, F. Priem, I. Jacquemond-Collet, K. Clément, and D. Lacasa, "1,2-Vinyldithiin from garlic inhibits differentiation and inflammation of human preadipocytes," Journal of Nutrition, vol. 139, no. 11, pp. 2055-2060, 2009.

[138] J. H. Lee, K. A. Kim, K. B. Kwon et al., "Diallyl disulfide accelerates adipogenesis in 3T3-L1 cells," International Journal of Molecular Medicine, vol. 20, no. 1, pp. 59-64, 2007.

[139] M. S. Quintero-Fabián, D. Ortuño-Sahagún, M. VázquezCarrera, and R. I. López-Roa, "Effect of alliin on the adipokines gene expression in an inflammatory in vitro model of 3T3-L1 adipocytes," in Proceedings of the 1st FALAN Meeting, 2012.

[140] A. L. Chen, C. H. Hsu, J. K. Lin et al., "Phase I clinical trial of curcumin, a chemopreventive agent, in patients with high-risk or pre-malignant lesions," Anticancer Research, vol. 21, no. 4, pp. 2895-2900, 2001.

[141] M. M. Y. Chan, "Inhibition of tumor necrosis factor by curcumin, a phytochemical," Biochemical Pharmacology, vol. 49, no. 11, pp. 1551-1556, 1995.

[142] I. Brouet and H. Ohshima, "Curcumin, an anti-tumour promoter and anti-inflammatory agent, inhibits induction of nitric oxide synthase in activated macrophages," Biochemical and Biophysical Research Communications, vol. 206, no. 2, pp. 533-540, 1995.

[143] M. M. Y. Chan, H. I. Huang, M. R. Fenton, and D. Fong, "In vivo inhibition of nitric oxide synthase gene expression by curcumin, a cancer preventive natural product with antiinflammatory properties," Biochemical Pharmacology, vol. 55, no. 12, pp. 1955-1962, 1998.

[144] J. S. Welch, M. Ricote, T. E. Akiyama, F. J. Gonzalez, and C. K. Glass, "PPAR $\gamma$ and $\operatorname{PPAR} \delta$ negatively regulate specific subsets of lipopolysaccharide and IFN- $\gamma$ target genes in macrophages," Proceedings of the National Academy of Sciences of the United States of America, vol. 100, no. 11, pp. 6712-6717, 2003.

[145] A. Chen and J. Xu, "Activation of PPAR $\gamma$ by curcumin inhibits Moser cell growth and mediates suppression of gene expression of cyclin D1 and EGFR," American Journal of Physiology, vol. 288, no. 3, pp. G447-G456, 2005.

[146] A. M. Siddiqui, X. Cui, R. Wu et al., "The anti-inflammatory effect of curcumin in an experimental model of sepsis is mediated by up-regulation of peroxisome proliferatoractivated receptor- $\gamma$," Critical Care Medicine, vol. 34, no. 7, pp. 1874-1882, 2006.

[147] N. Adapala and M. M. Chan, "Long-term use of an antiinflammatory, curcumin, suppressed type 1 immunity and exacerbated visceral leishmaniasis in a chronic experimental model," Laboratory Investigation, vol. 88, no. 12, pp. 13291339, 2008.

[148] S. Zheng and A. Chen, "Disruption of transforming growth factor- $\beta$ signaling by curcumin induces gene expression of peroxisome proliferator-activated receptor- $\gamma$ in rat hepatic stellate cells," American Journal of Physiology, vol. 292, no. 1, pp. G113-G123, 2007.

[149] A. Camins, F. Junyent, E. Verdaguer et al., "Resveratrol: an antiaging drug with potential therapeutic applications in treating diseases," Pharmaceuticals, vol. 2, no. 3, pp. 194-205, 2009.

[150] S. Rayalam, M. A. Della-Fera, J. Y. Yang, J. P. Hea, S. Ambati, and C. A. Baile, "Resveratrol potentiates genistein's antiadipogenic and proapoptotic effects in 3T3-L1 adipocytes," Journal of Nutrition, vol. 137, no. 12, pp. 2668-2673, 2007.

[151] Z. E. Floyd, Z. Q. Wang, G. Kilroy, and W. T. Cefalu, "Modulation of peroxisome proliferator-activated receptor $\gamma$ stability and transcriptional activity in adipocytes by resveratrol," Metabolism, vol. 57, no. 1, pp. S32-S38, 2008.

[152] H. Y. Zhang, Z. X. Du, and X. Meng, "Resveratrol prevents TNF $\alpha$-induced suppression of adiponectin expression via PPAR $\gamma$ activation in 3T3-L1 adipocytes," Clinical and Experimental Medicine. In press.

[153] C. D. S. Costa, F. Rohden, T. O. Hammes et al., "Resveratrol upregulated SIRT1, FOXO1, and adiponectin and downregulated PPAR $\gamma 1-3$ mRNA expression in human visceral adipocytes," Obesity Surgery, vol. 21, no. 3, pp. 356-361, 2011.

[154] Y. Zhang, Z. Luo, L. Ma, Q. Xu, Q. Yang, and L. Si, "Resveratrol prevents the impairment of advanced glycosylation end 
products (AGE) on macrophage lipid homeostasis by suppressing the receptor for AGE via peroxisome proliferatoractivated receptor $\gamma$ activation," International Journal of Molecular Medicine, vol. 25, no. 5, pp. 729-734, 2010.

[155] Z. Xu, X. Chen, Z. Zhong, L. Chen, and Y. Wang, "Ganoderma lucidum polysaccharides: immunomodulation and potential anti-tumor activities," American Journal of Chinese Medicine, vol. 39, no. 1, pp. 15-27, 2011.

[156] Y. Shimojo, K. Kosaka, and T. Shirasawa, "Effect of Ganoderma lucidum extract on adipocyte differentiation and adiponectin gene expression in the murine pre-adipocyte cell line, 3T3-L1," Phytotherapy Research, vol. 25, no. 2, pp. 202207, 2011.

[157] A. Thyagarajan-Sahu, B. Lane, and D. Sliva, "ReishiMax, mushroom based dietary supplement, inhibits adipocyte differentiation, stimulates glucose uptake and activates AMPK," BMC Complementary and Alternative Medicine, vol. 11, p. 74, 2011.

[158] M. H. Roberfroid, Inuline-Type Fructans Functional Foods Ingredients, CRC Series in Modern Nutrition, 2005.

[159] P. D. Cani and N. M. Delzenne, "Interplay between obesity and associated metabolic disorders: new insights into the gut microbiota," Current Opinion in Pharmacology, vol. 9, no. 6, pp. 737-743, 2009.

[160] M. Zenhom, A. Hyder, M. de Vrese, K. J. Heller, T. Roeder, and J. Schrezenmeir, "Prebiotic oligosaccharides reduce proinflammatory cytokines in intestinal Caco-2 cells via activation of PPAR $\gamma$ and peptidoglycan recognition protein 3," Journal of Nutrition, vol. 141, no. 5, pp. 971-977, 2011.

[161] G. Pattenden, "Natural 4-ylidenebutenolides and 4ylidenetetronic acids," Fortschritte der Chemie Organischer Naturstoffe, vol. 35, pp. 133-198, 1978.

[162] R. D. Haworth, "Natural resins," Annual Report on the Progress of Chemistry, vol. 33, p. 266, 1936.

[163] N. Fakhrudin, A. Ladurner, A. G. Atanasov et al., "Computeraided discovery, validation, and mechanistic characterization of novel neolignan activators of peroxisome proliferatoractivated receptor $\gamma$," Molecular Pharmacology, vol. 77, no. 4, pp. 559-566, 2010.

[164] J. Schrezenmeir and M. De Vrese, "Probiotics, prebiotics, and synbiotics-approaching a definition," American Journal of Clinical Nutrition, vol. 73, no. 2, pp. 361-364, 2001.

[165] B. Lam and Z. M. Younossi, "Review: treatment options for nonalcoholic fatty liver disease," Therapeutic Advances in Gastroenterology, vol. 3, no. 2, pp. 121-137, 2010.

[166] G. Zanello, F. Meurens, M. Berri, and H. Salmon, "Saccharomyces boulardii effects on gastrointestinal diseases," Current Issues in Molecular Biology, vol. 11, pp. 47-58, 2009.

[167] X. Wu, B. A. Vallance, L. Boyer et al., "Saccharomyces boulardii ameliorates Citrobacter rodentium-induced colitis through actions on bacterial virulence factors," American Journal of Physiology, vol. 294, no. 1, pp. G295-G306, 2007.

[168] I. Castagliuolo, M. F. Riegler, L. Valenick, J. T. LaMont, and C. Pothoulakis, "Saccharomyces boulardii protease inhibits the effects of Clostridium difficile toxins A and B in human colonic mucosa," Infection and Immunity, vol. 67, no. 1, pp. 302-307, 1999.

[169] K. L. Mumy, X. Chen, C. P. Kelly, and B. A. McCormick, "Saccharomyces boulardii interferes with Shigella pathogenesis by postinvasion signaling events," American Journal of Physiology, vol. 294, no. 3, pp. G599-G609, 2008.

[170] F. S. Martins, G. Dalmasso, R. M. E. Arantes et al., "Interaction of Saccharomyces boulardii with Salmonella enterica serovar typhimurium protects mice and modifies T84 cell response to the infection," PLOS ONE, vol. 5, no. 1, article e8925, 2010.

[171] G. Zanello, M. Berri, J. Dupont et al., "Saccharomyces cerevisiae modulates immune gene expressions and inhibits ETEC-mediated ERK1/2 and p38 signaling pathways in intestinal epithelial cells," PLOS ONE, vol. 6, no. 4, article e18573, 2011.

[172] S. K. Lee, H. J. Kim, S. G. Chi et al., "Saccharomyces boulardii activates expression of peroxisome proliferator-activated receptor-gamma in HT-29 cells," The Korean Journal of Gastroenterology, vol. 45, no. 5, pp. 328-334, 2005.

[173] C. Pothoulakis, "Review article: anti-inflammatory mechanisms of action of Saccharomyces boulardii," Alimentary Pharmacology and Therapeutics, vol. 30, no. 8, pp. 826-833, 2009.

[174] S. K. Lee, Y. W. Kim, S. G. Chi, Y. S. Joo, and H. J. Kim, "The effect of saccharomyces boulardii on human colon cells and inflammation in rats with trinitrobenzene sulfonic acidinduced colitis," Digestive Diseases and Sciences, vol. 54, no. 2, pp. 255-263, 2009.

[175] A. Nissle, "Die antagonistische behandlung chronischer darmstorungen mit colibakterien," Medizinische Klinik, vol. 2, pp. 29-33, 1918.

[176] C. A. Jacobi and P. Malfertheiner, "Escherichia coli Nissle 1917 (Mutaflor): new insights into an old probiotic bacterium," Digestive Diseases, vol. 29, no. 6, pp. 600-607, 2011.

[177] J. Schulze and U. Sonnenborn, "120 Jahre E. coli: bedeutung in forschung und medizin. Hagen: Alfred-NissleGesellschafte. V," 2006.

[178] P. C. Konturek, Z. Sliwowski, J. Koziel et al., "Probiotic bacteria Escherichia coli strain Nissle 1917 attenuates acute gastric lesions induced by stress," Journal of Physiology and Pharmacology, vol. 60, pp. 41-48, 2009.

[179] C. Reiff, M. Delday, G. Rucklidge et al., "Balancing inflammatory, lipid, and xenobiotic signaling pathways by VSL\#3, a biotherapeutic agent, in the treatment of inflammatory bowel disease," Inflammatory Bowel Diseases, vol. 15, no. 11, pp. 1721-1736, 2009.

[180] J. B. Ewaschuk, J. W. Walker, H. Diaz, and K. L. Madsen, "Bioproduction of conjugated linoleic acid by probiotic bacteria occurs in vitro and in vivo in mice," Journal of Nutrition, vol. 136, no. 6, pp. 1483-1487, 2006.

[181] O. Boss and N. Bergenhem, "Adipose targets for obesity drug development," Expert Opinion on Therapeutic Targets, vol. 10, no. 1, pp. 119-134, 2006.

[182] F. Bäckhed, H. Ding, T. Wang et al., "The gut microbiota as an environmental factor that regulates fat storage," Proceedings of the National Academy of Sciences of the United States of America, vol. 101, no. 44, pp. 15718-15723, 2004.

[183] F. Bäckhed, J. K. Manchester, C. F. Semenkovich, and J. I. Gordon, "Mechanisms underlying the resistance to diet-induced obesity in germ-free mice," Proceedings of the National Academy of Sciences of the United States of America, vol. 104, no. 3, pp. 979-984, 2007.

[184] L. Wen, R. E. Ley, P. Y. Volchkov et al., "Innate immunity and intestinal microbiota in the development of Type 1 diabetes," Nature, vol. 455, no. 7216, pp. 1109-1113, 2008.

[185] K. Einarsson, J. A. Gustafsson, and B. E. Gustafsson, "Differences between germ free and conventional rats in liver microsomal metabolism of steroids," The Journal of Biological Chemistry, vol. 248, no. 10, pp. 3623-3630, 1973.

[186] K. Einarsson, J. A. Gustafsson, and B. E. Gustafsson, "Hepatic 3 hydroxy 3 methylglutaryl CoA reductase activity in 
germfree rats," Proceedings of the Society for Experimental Biology and Medicine, vol. 154, no. 3, pp. 319-321, 1977.

[187] B. E. Gustafsson, B. Angelin, K. Einarsson, and J. A. Gustafsson, "Effects of cholesterol feeding on synthesis and metabolism of cholesterol and bile acids in germfree rats," Journal of Lipid Research, vol. 18, no. 6, pp. 717-721, 1977.

[188] P. Desreumaux, L. Dubuquoy, S. Nutten et al., "Attenuation of colon inflammation through activators of the retinoid $\mathrm{X}$ receptor $(\mathrm{RXR}) /$ peroxisome proliferator-activated receptor $\gamma$ (PPAR $\gamma$ ) heterodimer: a basis for new therapeutic strategies," Journal of Experimental Medicine, vol. 193, no. 7, pp. 827838, 2001.

[189] A. Chawla, Y. Barak, L. Nagy, D. Liao, P. Tontonoz, and R. M. Evans, "PPAR- $\gamma$ dependent and independent effects on macrophage-gene expression in lipid metabolism and inflammation," Nature Medicine, vol. 7, no. 1, pp. 48-52, 2001.

[190] P. Vavassori, A. Mencarelli, B. Renga, E. Distrutti, and S. Fiorucci, "The bile acid receptor FXR is a modulator of intestinal innate immunity," Journal of Immunology, vol. 183, no. 10, pp. 6251-6261, 2009.

[191] G. Rumi, R. Tsubouchi, M. Okayama, S. Kato, G. Mózsik, and K. Takeuchi, "Protective effect of lactulose on dextran sulfate sodium-induced colonic inflammation in rats," Digestive Diseases and Sciences, vol. 49, no. 9, pp. 1466-1472, 2004.

[192] F. Lara-Villoslada, E. Debras, A. Nieto et al., "Oligosaccharides isolated from goat milk reduce intestinal inflammation in a rat model of dextran sodium sulfate-induced colitis," Clinical Nutrition, vol. 25, no. 3, pp. 477-488, 2006.

[193] J. O. Lindsay, K. Whelan, A. J. Stagg et al., "Clinical, microbiological, and immunological effects of fructo-oligosaccharide in patients with Crohn's disease," Gut, vol. 55, no. 3, pp. 348355, 2006.

[194] J. Winkler, R. Butler, and E. Symonds, "Fructo-oligosaccharide reduces inflammation in a dextran sodium sulphate mouse model of colitis," Digestive Diseases and Sciences, vol. 52, no. 1, pp. 52-58, 2007.

[195] P. L. Lakatos, "Recent trends in the epidemiology of inflammatory bowel diseases: up or down?" World Journal of Gastroenterology, vol. 12, no. 38, pp. 6102-6108, 2006.

[196] S. B. Joseph, A. Castrillo, B. A. Laffitte, D. J. Mangelsdorf, and P. Tontonoz, "Reciprocal regulation of inflammation and lipid metabolism by liver X receptors," Nature Medicine, vol. 9, no. 2, pp. 213-219, 2003.

[197] S. Fiorucci, S. Cipriani, A. Mencarelli, B. Renga, E. Distrutti, and F. Baldelli, "Counter-regulatory role of bile acid activated receptors in immunity and inflammation," Current Molecular Medicine, vol. 10, no. 6, pp. 579-595, 2010.

[198] T. Mach, "Clinical usefulness of probiotics in inflammatory bowel diseases," Journal of Physiology and Pharmacology, vol. 57, no. 9, pp. 23-33, 2006.

[199] L. Dubuquoy, C. Rousseaux, X. Thuru et al., "PPAR $\gamma$ as a new therapeutic target in inflammatory bowel diseases," Gut, vol. 55, no. 9, pp. 1341-1349, 2006.

[200] J. Bassaganya-Riera and R. Hontecillas, "Dietary conjugated linoleic acid and n-3 polyunsaturated fatty acids in inflammatory bowel disease," Current Opinion in Clinical Nutrition and Metabolic Care, vol. 13, no. 5, pp. 569-573, 2010.

[201] N. Nieto, M. I. Torres, A. Ŕos, and A. Gil, "Dietary polyunsaturated fatty acids improve histological and biochemical alterations in rats with experimental ulcerative colitis," Journal of Nutrition, vol. 132, no. 1, pp. 11-19, 2002.
[202] D. Q. Shih and S. R. Targan, "Immunopathogenesis of inflammatory bowel disease," World Journal of Gastroenterology, vol. 14, no. 3, pp. 390-400, 2008.

[203] P. Desreumaux, O. Ernst, K. Geboes et al., "Inflammatory alterations in mesenteric adipose tissue in Crohn's disease," Gastroenterology, vol. 117, no. 1, pp. 73-81, 1999.

[204] A. Schäffler, J. Schölmerich, and C. Büchler, "Mechanisms of disease: adipocytokines and visceral adipose tissueemerging role in nonalcoholic fatty liver disease," Nature Clinical Practice Gastroenterology and Hepatology, vol. 2, no. 6, pp. 273-280, 2005.

[205] I. Karagiannides, E. Kokkotou, M. Tansky et al., "Induction of colitis causes inflammatory responses in fat depots: evidence for substance P pathways in human mesenteric preadipocytes," Proceedings of the National Academy of Sciences of the United States of America, vol. 103, no. 13, pp. 5207-5212, 2006.

[206] N. Frey, H. A. Katus, E. N. Olson, and J. A. Hill, "Hypertrophy of the heart: a new therapeutic target?" Circulation, vol. 109, no. 13, pp. 1580-1589, 2004.

[207] R. De Caterina, A. Zampolli, S. Del Turco, R. Madonna, and M. Massaro, "Nutritional mechanisms that influence cardiovascular disease," American Journal of Clinical Nutrition, vol. 83, no. 2, pp. 421S-426S, 2006.

[208] C. Wang, W. S. Harris, M. Chung et al., "n-3 Fatty acids from fish or fish-oil supplements, but not $\alpha$-linolenic acid, benefit cardiovascular disease outcomes in primary- and secondaryprevention studies: a systematic review," American Journal of Clinical Nutrition, vol. 84, no. 1, pp. 5-17, 2006. 


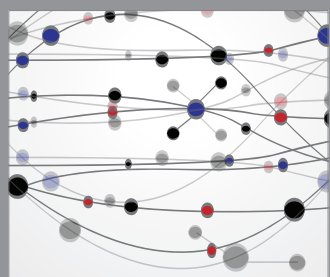

The Scientific World Journal
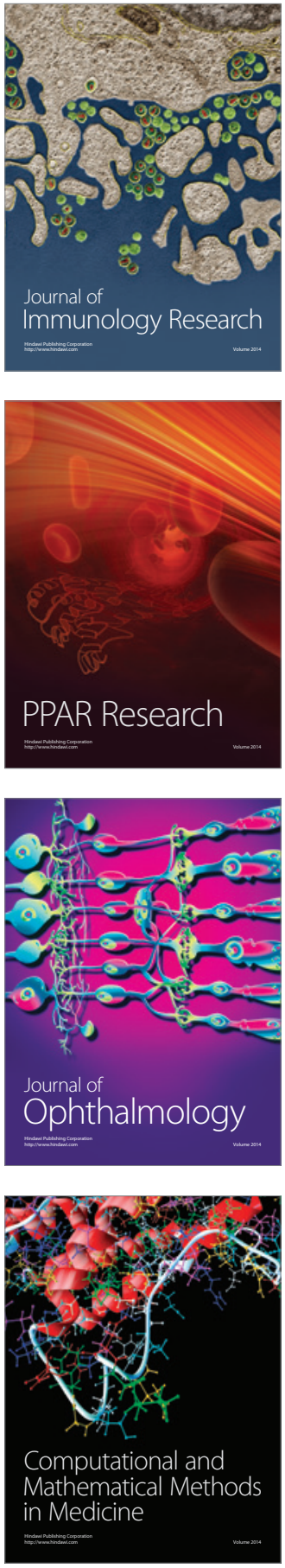

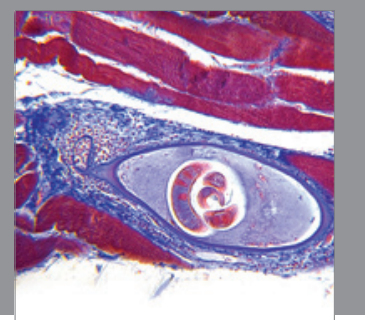

Gastroenterology

Research and Practice
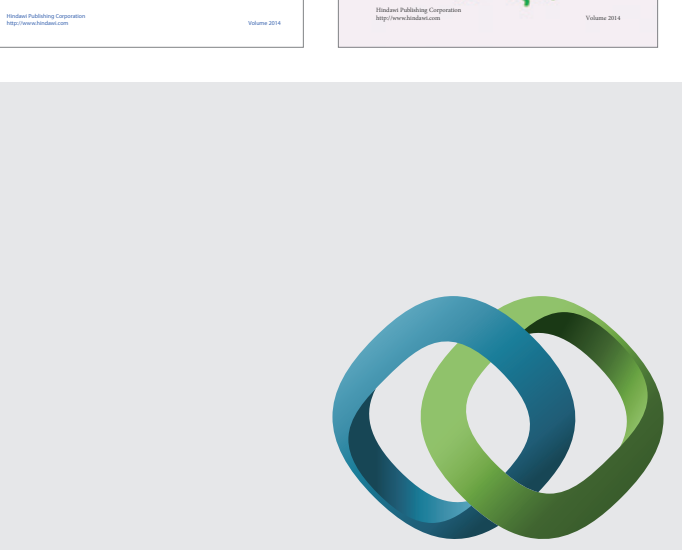

\section{Hindawi}

Submit your manuscripts at

http://www.hindawi.com
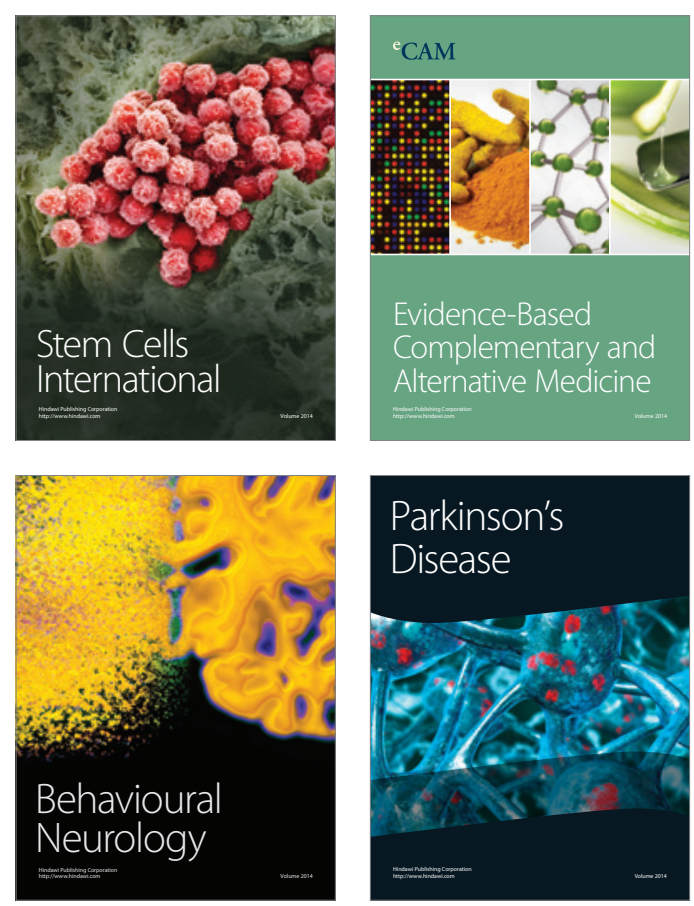

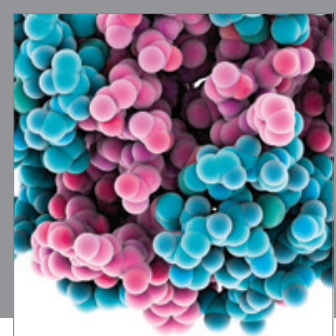

Journal of
Diabetes Research

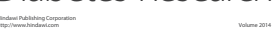

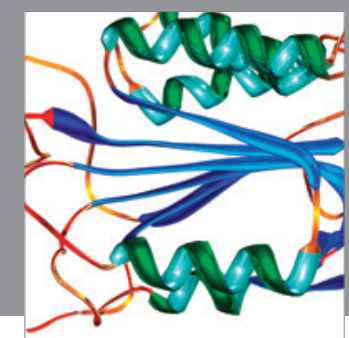

Disease Markers
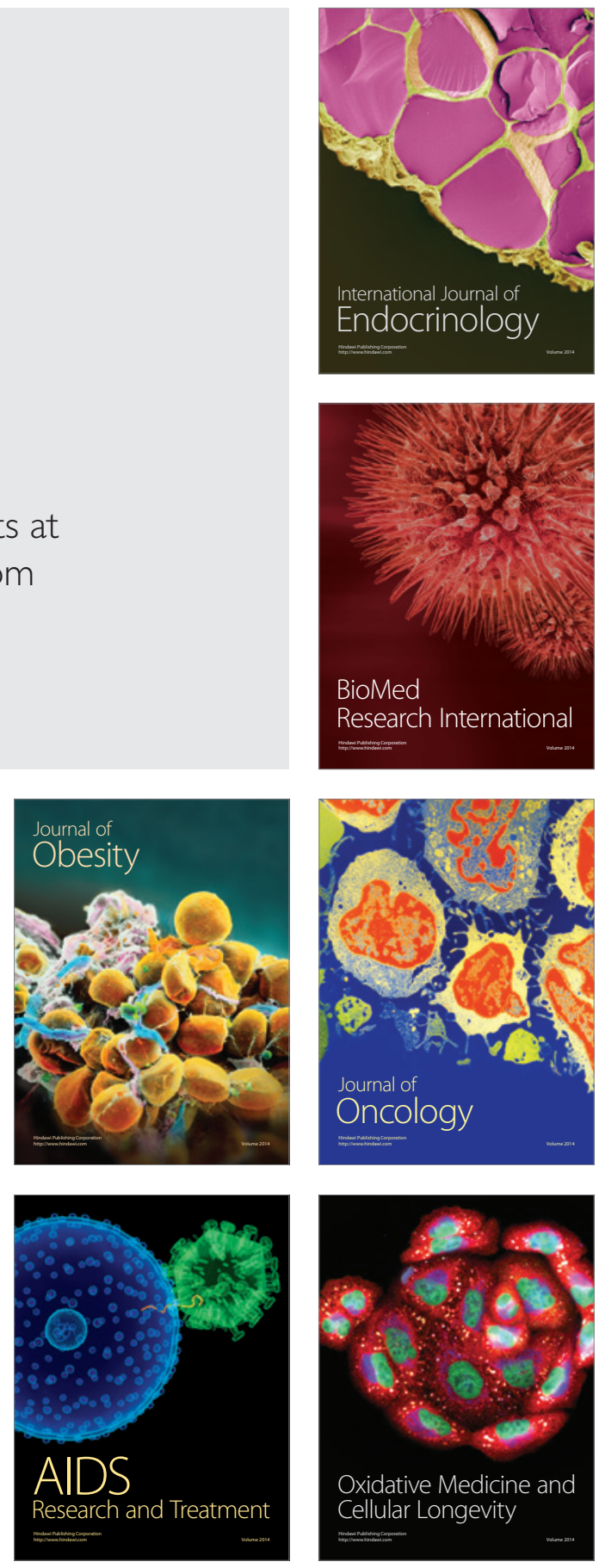